Article

\title{
Germination and Growth of Spinach under Potassium Deficiency and Irrigation with High-Salinity Water
}

\author{
Kadir Uçgun ${ }^{1}{ }^{\circledR}$, Jorge F. S. Ferreira ${ }^{2, *}$, Xuan Liu ${ }^{2}$, Jaime Barros da Silva Filho ${ }^{3}$, \\ Donald L. Suarez ${ }^{2}$, Claudivan F. de Lacerda ${ }^{4}$ and Devinder Sandhu ${ }^{2}$ (D) \\ 1 Department of Plant and Animal Production, Technical Sciences Vocational School, \\ Karamanoğlu Mehmetbey University, Karaman 70200, Turkey; kadirucgun@kmu.edu.tr \\ 2 US Salinity Laboratory (USDA-ARS), 450 W. Big Springs Rd., Riverside, CA 92507, USA; \\ xuan.liu@usda.gov (X.L.); donald.suarez@usda.gov (D.L.S.); devinder.sandhu@usda.gov (D.S.) \\ 3 Departments of Microbiology and Plant Pathology, University of California Riverside, 900 University Ave., \\ Riverside, CA 92521, USA; jaimeba@ucr.edu \\ 4 Department of Agricultural Engineering, Federal University of Ceará, Fortaleza-CE 60450-760, Brazil; \\ cfeitosa@ufc.br \\ * Correspondence: jorge.ferreira@usda.gov
}

Received: 26 September 2020; Accepted: 6 December 2020; Published: 9 December 2020

\begin{abstract}
Information is scarce on the interaction of mineral deficiency and salinity. We evaluated two salt-tolerant spinach cultivars under potassium $(\mathrm{K})$ doses $\left(0.07,0.15,0.3\right.$, and $\left.3.0 \mathrm{mmol}_{\mathrm{C}} \mathrm{L}^{-1}\right)$ and saline irrigation $\left(5,30,60,120\right.$, and $\left.160 \mathrm{mmol}_{\mathrm{c}} \mathrm{L}^{-1} \mathrm{NaCl}\right)$ during germination and growth. There was no interaction between salinity and K. Salinity decreased germination percent (GP), not always significantly, and drastically reduced seedling biomass. 'Raccoon' significantly increased GP at $60 \mathrm{mmol}_{\mathrm{C}} \mathrm{L}^{-1}$ while 'Gazelle' maintained GP up to 60 or $120 \mathrm{mmol}_{\mathrm{C}} \mathrm{L}^{-1}$. After 50 days under saline irrigation, shoot biomass increased significantly at 30 and $60 \mathrm{mmol}_{\mathrm{C}} \mathrm{L}^{-1}$ at the lowest $\mathrm{K}$ dose but, in general, neither salinity nor K dose affected shoot biomass, suggesting that salinity supported plant growth at the most K-deficient dose. Salinity did not affect shoot N, P, or K but significantly reduced $\mathrm{Ca}, \mathrm{Mg}$, and $\mathrm{S}$, although plants had no symptoms of salt toxicity or mineral deficiency. Although spinach seedlings are more sensitive to salt stress, plants adjusted to salinity with time. Potassium requirement for spinach growth was less than the current crop recommendation, allowing its cultivation with waters of moderate to high salinity without considerable reduction in yield, appearance, or mineral composition.
\end{abstract}

Keywords: Spinacia oleracea; potassium deficiency; high-salinity water; potassium-salinity interaction; salt-tolerant glycophyte

\section{Introduction}

The undesirable effects of salt stress on plant growth can be associated with (1) soil solution with low osmotic potential (water stress), (2) nutrient imbalance caused by excessive $\mathrm{NaCl}$ or by high soil $\mathrm{pH}$, (3) specific ion effect $\left(\mathrm{Na}^{+}\right.$and/or $\left.\mathrm{Cl}^{-}\right)$, or (4) a combination of all three factors [1]. These factors cause adverse effects on plant growth and yield $[2,3]$ and, when severe and prolonged, will lead to plant death. The most prevalent ions in salt-affected soils or saline irrigation water are $\mathrm{Na}^{+}$and $\mathrm{Cl}^{-}$ and the great majority of salt stress is due to either one or both ions because they are highly soluble and become toxic to plants at high concentrations. These ions compete with the absorption of $\mathrm{K}^{+}, \mathrm{Ca}^{2+}$, and $\mathrm{NO}^{-}$and often lead to pertinent mineral nutrient imbalance and deficiency [4]. Recent reports indicate that the effects of competition between different ions depend on their tissue concentration and may vary with plant species [5-7]. 
Depending on water or soil salinity, $\mathrm{Na}$ and $\mathrm{Cl}$ can accumulate in spinach shoots at levels as high as the macronutrients $\mathrm{N}$ and $\mathrm{K}[6,8]$, indicating the existence of an efficient vacuolar sequestration of potentially toxic $\mathrm{Na}^{+}$and $\mathrm{Cl}^{-}$ions in this species. On the contrary, many glycophytes, including strawberry and Jerusalem artichoke, have mechanisms that prevent $\mathrm{Na}^{+}$toxicity by reducing $\mathrm{Na}^{+}$transport to leaves [5,9]. However, these mechanisms are not so efficient in controlling $\mathrm{Cl}^{-}$ absorption and translocation in most glycophytic plants, making $\mathrm{Cl}^{-}$one of the main ions responsible for specific-ion toxicity. Thus, $\mathrm{Cl}$ alone, or associated with $\mathrm{Na}$, may decrease plant performance after their excessive tissue accumulation $[5,10]$.

Germination is highly influenced by environmental factors [11] and is a complex phenomenon involving many physiological and biochemical changes that are easily compromised by stress, including salt stress [12]. Salinity can affect the germination of seeds either by lowering soil osmotic potential and reducing water uptake by plant roots or by toxic effects caused by specific ions [13]. Salinity stress can change the activity of enzymes of the nucleic acid metabolism [14], alter protein metabolism [15,16], disturb hormonal balance [17], and reduce the utilization of seed reserves [18,19].

Data from several crops suggest that the level of salinity tolerance is highly dependent on the plant species [20,21], the cultivar within a species [9,22-24] or on the developmental stage of the plant [25]. Several researchers investigated the effect of salinity on the germination of plants like beans [26], quinoa [27,28], tomato [29], cabbage [30], cauliflower [30], canola [30,31], cowpea [32], onion [33], safflower [34], sunflower [35], eggplant [36] carrot [37], and spinach [20]. Salinity reduced germination rates in all of them.

Although it is known that salinity affects plant developmental stages differently, it is not known whether this would be associated with the duration of each stage or with the existence of specific mechanisms to maintain needed tissue levels of mineral nutrients for plant growth. For example, it is known that excess $\mathrm{NaCl}$ affects the absorption and accumulation of $\mathrm{K}$ in the leaves of many species, resulting in damage to cellular metabolism. In salt-tolerant species, however, Na may partially replace $\mathrm{K}$ to a great extent, but without damaging plant growth [38]. Thus, an important question arises: is this partial replacement of $\mathrm{K}$ by $\mathrm{Na}$ maintained and/or beneficial at all stages of the crop cycle? Furthermore, although it is known that salinity may affect the absorption of major mineral ions such as $\mathrm{K}^{+}$and $\mathrm{NO}_{3}{ }^{-}$in most glycophytes, there is no published data reporting the effect of moderate to high salinity of irrigation water, combined with deficient soil concentrations of either $\mathrm{NO}_{3}{ }^{-}$or $\mathrm{K}^{+}$, on spinach germination and growth. Even data on ideal mineral (N, P, and K) nutrition for spinach without salinity was lacking until recently [39].

Considering that spinach is a moderately salt-tolerant glycophyte $[6,8,40]$, we hypothesized that irrigation waters providing elevated $\mathrm{NaCl}$-induced salinity combined with potassium deficiency would mimic similar conditions found in soil solutions, thus providing a model system to study spinach response to these stresses at both germination and late growth stage. Thus, the objective of this research was to examine the salt tolerance of two cultivars of spinach at different developmental stages (germination, seedling establishment, and vegetative growth) under cultivation with elevated salinity combined with $\mathrm{K}$ deficiency applied through the irrigation water.

\section{Materials and Methods}

\subsection{Greenhouse Cultivation Details}

Riverside, California, is situated at an altitude of $311 \mathrm{~m}$ with a latitude of $33.9^{\circ} 57^{\prime} 54^{\prime \prime} \mathrm{N}$ and a longitude of $117.3^{\circ} 20^{\prime} 13^{\prime \prime} \mathrm{W}$. Although ideal temperatures for spinach growth are between 15 and $18^{\circ} \mathrm{C}$, the crop grows well in temperatures ranging from 5 to $30^{\circ} \mathrm{C}$ [41]. Thus, greenhouse temperature control was set between $15^{\circ} \mathrm{C}$ (night) and $28^{\circ} \mathrm{C}$ (day). The greenhouse cultivation of both experiments spun from 19 October 2018 to 11 March 2019. During that time, spinach plants were grown under short days with $13-13.5 \mathrm{~h}$ dark/10.5 to $11.0 \mathrm{~h}$ of natural light, which is under the flowering inductive 
photoperiod (14 $\mathrm{h} \mathrm{day}^{-1}$ ) for spinach [42]. Minimum to maximum greenhouse average relative humidity, temperature, day length, and light intensity are shown in Table 1.

Table 1. Average (minimum/maximum) relative humidity (ARH), temperature, and light intensity as photosynthetic photon flux density (PPFD) per month in a greenhouse used for the germination and growth of spinach cv. Raccoon and Gazelle. Fall and winter in California were from 23 September-21 December 2018 and from 22 December 2018-19 March 2019.

\begin{tabular}{|c|c|c|c|c|}
\hline Date & ARH (\%) & $\begin{array}{c}\text { Temp } \\
\left({ }^{\circ} \mathrm{C}\right)\end{array}$ & 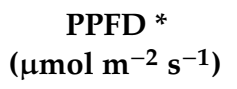 & $\begin{array}{l}\text { Day Length ** } \\
\text { (h:min:s) }\end{array}$ \\
\hline $\begin{array}{l}\text { October 19/2018 } \\
(\mathrm{min} / \mathrm{max})\end{array}$ & $5.0 / 66.0$ & $22.2 / 31.8$ & $433.0 / 624.4$ & $11: 12: 36$ \\
\hline $\begin{array}{l}\text { November/2018 } \\
(\mathrm{min} / \mathrm{max})\end{array}$ & $3.0 / 73.4$ & $19.8 / 30.1$ & $224.4 / 517.6$ & 10:04:37 \\
\hline $\begin{array}{l}\text { December/2018 } \\
(\mathrm{min} / \mathrm{max})\end{array}$ & 10.0/71.0 & $15.6 / 28.0$ & $222.8 / 423.0$ & 09:56:06 \\
\hline $\begin{array}{c}\text { January/2019 } \\
(\min / \max )\end{array}$ & $8.0 / 69.0$ & $14.6 / 27.8$ & $200.0 / 458.6$ & $10: 31: 53$ \\
\hline $\begin{array}{c}\text { February/2019 } \\
(\min / \max )\end{array}$ & $18.0 / 61.3$ & $13.1 / 31.1$ & $427.0 / 634.4$ & $11: 25: 28$ \\
\hline $\begin{array}{l}\text { March 11/2019 } \\
(\min / \max )\end{array}$ & $30.0 / 66.0$ & $17.0 / 30.7$ & $351.6 / 771.2$ & $11: 48: 34$ \\
\hline
\end{tabular}

* PPFD was estimated for 8.5-9.0 h day ${ }^{-1}$ (from 7:00 a.m. to 5:00 p.m.) with approximately half the hours averaged for minimum and half for maximum PPFD. Sensor was from Apogee Instruments, Inc. (Logan, UT, USA). ** Daylength data are given from 19 October 2018 to 11 March 2019, and for the last day of each month, except for October and March (daylength for 1st and last day of experiment only). Daylength data source: https://www.timeanddate.com/sun/usa/riverside.

Two experiments were conducted to evaluate the effects of $\mathrm{NaCl}$ doses and $\mathrm{K}$ deficiency, separately and combined, under greenhouse conditions on two spinach (Spinacia oleracea L.) cultivars (Raccoon and Gazelle). One experiment focused on assessing germination and seedling establishment (4-6 true leaves). The other experiment was carried out to assess vegetative growth, when salinity was applied to plants with 6-8 true leaves and continued for seven weeks until harvest. The pots were arranged in a randomized complete block design with four replicates, each with 3 plants per pot. Both experiments had 20 treatments assigned to each cultivar (combination of $5 \mathrm{NaCl}$ concentrations with $4 \mathrm{~K}$ doses: 3 deficient and 1 control) with a total of 80 pots per cultivar, in a factorial arrangement.

For Experiment 1 (germination and seedling establishment), five seeds were sown directly at a depth of $1.3 \mathrm{~cm}$ in $5.7-\mathrm{L}$ pots $(22.2 \mathrm{~cm}$ in diameter) on 07 February 2019. Pots were filled with non-washed, non-sterile, sand and saturated with the pertinent treatment solution. After sowing, pots were irrigated three times a week with each saline treatment solution. Data on seed gemination were recorded daily between 13 and 32 days after sowing for each cultivar. All Seedlings from germinated seeds (no thinning was performed in this experiment) were harvested on the 32nd day after sowing 11 March 2019) with shoots separated from roots and recorded for shoot fresh weight (SFW). The coefficient of velocity of germination (CVG in $\%$ day $^{-1}$ ) and the germination percentage (GP) at 13, 22, and 32 days were obtained according to [43], as follow:

CVG $\left(\%\right.$ day $\left.^{-1}\right)=\left[\sum \mathrm{Ni} / \sum(\mathrm{NiTi})\right] \times 100$, where $\mathrm{N}$ was the number of seeds germinated on day $\mathrm{i}$, $\mathrm{Ti}$ is the number of days from sowing and GP $(\%)=$ No. of seeds germinated per cultivar at: 13 days for 'Gazelle', 22 days for 'Raccoon', and 32 days for both cultivars $\times 100$.

For Experiment 2 (vegetative growth), 7 seeds were sown directly into pots at $1.3 \mathrm{~cm}$ depth. Seeds were sown on 19 October 2018 and harvested on 28 January 2019 (101 days). Pots had the same dimensions and growth medium as described above. After germination, plants were thinned to the most homogeneous three plants per pot. Plants were watered with 1/8-strength Hoagland's nutrition solution [44] made with Riverside municipal water with an electrical conductivity $\left(\mathrm{EC}_{\mathrm{iw}}\right)$ of $0.7 \mathrm{dS} \mathrm{m} \mathrm{m}^{-1}$ three times a week until the growth stage of 6-8 true leaves. Salinity treatments were 
applied on 10 December 2018 and continued until 28 January 2019. Before treatments were applied, all pots were flushed four times with deionized water to remove any remaining fertilizer (including $\mathrm{K}$ ) from the sand. After that, treatments combining $\mathrm{Na}$ (as $\mathrm{NaCl}$ ) and $\mathrm{K}$ (substituting $\mathrm{K}$ for $\mathrm{Na}$ ) began and continued for 7 weeks (50 days) with harvest taking place from 29 January to 1 February 2019. All solutions (control and salt treatments) contained all macronutrients and micronutrients needed for spinach growth, as previously determined [6]. Solution volumes used to water plants were determined to allow leaching of approximately 30\% (water volume drained/volume applied) for both experiments. At harvest, all three plants in each pot were separated into shoots and roots. Unwashed shoots were weighed immediately upon harvest to obtain shoot fresh weight (SFW, g pot $\left.{ }^{-1}\right)$. Then, shoots and roots were washed with tap water, twice with deionized water to remove remaining sand (roots) and mineral fertilizers from tissue surface (shoots and roots) before drying in a forced-air oven $\left(70{ }^{\circ} \mathrm{C}\right)$ for at least $48 \mathrm{~h}$ to obtain constant shoot and root dry weight (SDW and RDW, respectively) in $\mathrm{g} \mathrm{pot}^{-1}$ before grinding for mineral analysis.

\subsection{Plant Mineral Analyses}

In experiment 1 (germination and seedling establishment) plants were too small for mineral analysis and only the fresh weight of shoots was recorded. For Experiment 2, plants were harvested, separated into shoots and roots, washed with tap water, followed by deionized water and blotted dry with paper towels and bagged to be dried in a forced-air oven at $70{ }^{\circ} \mathrm{C}$ until stable dry weight. Dry weight was recorded for shoots and roots. Samples were then ground in a Wiley mill to pass a 20-mesh $(0.84 \mathrm{~mm})$ screen. Tissue mineral concentration was based on shoot or root dry weight. Chloride was determined from nitric/acetic acid extracts by amperometric titration. The concentrations of tissue $\mathrm{Na}, \mathrm{P}, \mathrm{K}, \mathrm{Ca}, \mathrm{Mg}$, and total-S, and of the micronutrients $\mathrm{Fe}, \mathrm{Cu}, \mathrm{Mn}, \mathrm{Zn}$, and Mo were determined from nitric acid digestions (Milestone, Ethos EZ Microwave Digestion, Shelton, CT, USA) of the dried, ground, plant material by Inductively Coupled Plasma Optical Emission Spectrometry (ICP-OES, 3300DV, Perkin-Elmer Corp., Waltham, MA, USA). Nitrogen was determined by combustion in a Rapid N Exceed®analyzer (rNex, Elementar Americas Inc., Ronkonkoma, New York, NY, USA).

\subsection{Saline Solutions}

Saline solutions of the same salt composition were used as treatments in both experiments. In all, there were 20 treatments containing 5 nominal concentrations of $\mathrm{Na}(5,30,60,120$,

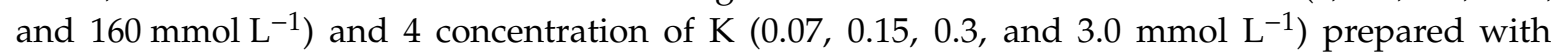
deionized water $\left(\mathrm{EC}_{\mathrm{w}}=0.05 \mathrm{dS} \mathrm{m}^{-1}\right)$. $\mathrm{NaCl}$ and $\mathrm{K}$ (partially substitute for $\mathrm{Na}$ ) were added to a basic, modified (no K), $\frac{1}{2}$-strength Hoagland's solution (Control) containing the same concentrations of macro- and micronutrients and 0.5-3.5 mmol L $\mathrm{m}^{-1}$ of $\mathrm{Na}^{+}$(Table 2). The solutions were constructed and balanced using the free software ExtractChem V. 2.0 (by Suarez and Taber, Agricultural Water Use Efficiency and Salinity Research Unit in Riverside, or US Salinity Laboratory (USDA-ARS) and available at: https://www.ars.usda.gov/research/software/download/?softwareid=155\&modecode=20-36-15-00.

The following salts were used to obtain target salinities in irrigation solution: $\mathrm{NaCl}$, $\mathrm{Ca}\left(\mathrm{NO}_{3}\right)_{2} \cdot 4 \mathrm{H}_{2} \mathrm{O}, \mathrm{NaNO}_{3}, \mathrm{KNO}_{3}, \mathrm{KCl}, \mathrm{NaH}_{2} \mathrm{PO}_{4}, \mathrm{MgSO}_{4} \cdot 7 \mathrm{H}_{2} \mathrm{O}$ (Table 1). NaFe-EDTA (0.05 mM), $\mathrm{H}_{3} \mathrm{BO}_{3}(0.023 \mathrm{mM}), \mathrm{MnSO}_{4} \cdot \mathrm{H}_{2} \mathrm{O}(0.005 \mathrm{mM}), \mathrm{ZnSO}_{4} .7 \mathrm{H}_{2} \mathrm{O}(0.0004 \mathrm{mM}), \mathrm{CuSO}_{4} \cdot 5 \mathrm{H}_{2} \mathrm{O}(0.0003 \mathrm{mM})$, and $\left(\mathrm{NH}_{4}\right)_{6} \mathrm{Mo}_{7} \mathrm{O}_{24} \cdot 4 \mathrm{H}_{2} \mathrm{O}(0.0001 \mathrm{mM})$ were added to every solution to meet plant micronutrient requirements. The concentrations of $\mathrm{K}^{+}$were achieved by substituting varying amounts of $\mathrm{KNO}_{3}$ for $\mathrm{NaNO}_{3}$ to achieve target $\mathrm{K}^{+}$levels. This resulted in slight decreases in $\mathrm{Na}^{+}$with increasing $\mathrm{K}+$ that are insignificant, relative to the amounts of total $\mathrm{Na}+$ applied, with real values given in Table 2 . However, to simplify the presentation of results and discussion, we will refer to the Na doses with the nominal values of $5,30,60,120$, and $160 \mathrm{mmol}_{\mathrm{C}} \mathrm{L}^{-1}$. 
Table 2. Cation and anion concentrations of saline solutions used to irrigate seeds (germination experiment) for 32 days (up to 4-6 true-leaf stage) and young plants bearing 6-8 true leaves for seven weeks (growth experiment).

\begin{tabular}{|c|c|c|c|c|c|c|c|c|c|c|c|}
\hline \multirow{2}{*}{ Treatment } & $\mathrm{K}^{+}$ & $\mathrm{Na}^{+}$ & $\mathrm{Cl}^{-}$ & $\mathrm{H}_{2} \mathrm{PO}_{4}^{-}$ & $\mathrm{Ca}^{2+}$ & $\mathrm{Mg}^{2+}$ & $\mathrm{SO}_{4}{ }^{2-}$ & $\mathrm{NO}_{3}{ }^{-}$ & TEC $_{\text {iw }}$ & $\mathrm{MEC}_{\mathrm{iw}}$ & \multirow{2}{*}{$\mathrm{pH}$} \\
\hline & & \multicolumn{6}{|c|}{$\left(\mathrm{mmol}_{\mathrm{c}} \mathrm{L}^{-1}\right)$} & \multicolumn{3}{|c|}{$\left(\mathrm{dS} \mathrm{m} \mathrm{m}^{-1}\right)$} & \\
\hline $\mathrm{T} 1$ & 0.07 & 3.5 & 0.07 & 0.5 & 5.0 & 2.0 & 2.0 & 8.0 & 1.0 & 1.3 & 6.14 \\
\hline $\mathrm{T} 2$ & 0.07 & 30.5 & 27.07 & 0.5 & 5.0 & 2.0 & 2.0 & 8.0 & 4.0 & 4.1 & 6.05 \\
\hline $\mathrm{T} 3$ & 0.07 & 60.5 & 57.07 & 0.5 & 5.0 & 2.0 & 2.0 & 8.0 & 7.2 & 7.2 & 6.15 \\
\hline $\mathrm{T} 4$ & 0.07 & 120.5 & 117.07 & 0.5 & 5.0 & 2.0 & 2.0 & 8.0 & 13.2 & 12.7 & 6.07 \\
\hline $\mathrm{T} 5$ & 0.07 & 160.5 & 157.07 & 0.5 & 5.0 & 2.0 & 2.0 & 8.0 & 17.1 & 16.8 & 6.09 \\
\hline T6 & 0.15 & 3.5 & 0.15 & 0.5 & 5.0 & 2.0 & 2.0 & 8.0 & 1.1 & 1.2 & 6.22 \\
\hline $\mathrm{T} 7$ & 0.15 & 30.5 & 27.15 & 0.5 & 5.0 & 2.0 & 2.0 & 8.0 & 4.0 & 4.0 & 6.17 \\
\hline $\mathrm{T} 8$ & 0.15 & 60.5 & 57.15 & 0.5 & 5.0 & 2.0 & 2.0 & 8.0 & 7.2 & 7.2 & 6.15 \\
\hline T9 & 0.15 & 120.5 & 117.15 & 0.5 & 5.0 & 2.0 & 2.0 & 8.0 & 13.2 & 13.2 & 6.18 \\
\hline $\mathrm{T} 10$ & 0.15 & 160.5 & 157.15 & 0.5 & 5.0 & 2.0 & 2.0 & 8.0 & 17.1 & 16.8 & 6.12 \\
\hline T11 & 0.3 & 3.5 & 0.30 & 0.5 & 5.0 & 2.0 & 2.0 & 8.0 & 1.1 & 1.3 & 6.19 \\
\hline $\mathrm{T} 12$ & 0.3 & 30.5 & 27.30 & 0.5 & 5.0 & 2.0 & 2.0 & 8.0 & 4.1 & 4.1 & 6.17 \\
\hline T13 & 0.3 & 60.5 & 57.30 & 0.5 & 5.0 & 2.0 & 2.0 & 8.0 & 7.2 & 7.4 & 6.21 \\
\hline $\mathrm{T} 14$ & 0.3 & 120.5 & 117.30 & 0.5 & 5.0 & 2.0 & 2.0 & 8.0 & 13.2 & 13.2 & 6.16 \\
\hline $\mathrm{T} 15$ & 0.3 & 160.5 & 157.30 & 0.5 & 5.0 & 2.0 & 2.0 & 8.0 & 17.1 & 16.9 & 6.09 \\
\hline T16 & 3.0 & 0.5 & 0.00 & 0.5 & 5.0 & 2.0 & 2.0 & 8.0 & 1.1 & 1.2 & 6.25 \\
\hline $\mathrm{T} 17$ & 3.0 & 27.5 & 27.00 & 0.5 & 5.0 & 2.0 & 2.0 & 8.0 & 4.1 & 4.8 & 6.17 \\
\hline T18 & 3.0 & 57.5 & 57.00 & 0.5 & 5.0 & 2.0 & 2.0 & 8.0 & 7.3 & 7.2 & 6.18 \\
\hline T19 & 3.0 & 117.5 & 117.00 & 0.5 & 5.0 & 2.0 & 2.0 & 8.0 & 13.2 & 13.2 & 6.18 \\
\hline T20 & 3.0 & 157.5 & 157.00 & 0.5 & 5.0 & 2.0 & 2.0 & 8.0 & 17.1 & 16.7 & 6.13 \\
\hline
\end{tabular}

$\mathrm{TEC}_{\mathrm{iw}}$ : Target electric conductivity of treatment irrigation water $\left(\mathrm{EC}_{\mathrm{iw}}\right), \mathrm{MEC}_{\mathrm{iw}}$ : Measured $\mathrm{EC}_{\mathrm{iw}}$ in treatment irrigation waters.

\subsection{Statistical Analyses}

Data for each cultivar was used for analyses of variance. Means were compared using Fisher's LSD test $(p<0.05)$. Statistical analysis was performed using SAEG version 9.1 [45] and the SigmaPlot/SigmaStat version 14.0 (Systat Software, San Jose, CA, USA, www.systatsoftware.com) software. Interactions were analyzed regardless of the significance of the $\mathrm{F}$ test. All interactions between $\mathrm{Na}$ and $\mathrm{K}$ doses were analyzed statistically independently of the significance of the $\mathrm{F}$ test. Analysis was also done for individual effects of either $\mathrm{Na}$ or $\mathrm{K}$ doses for all the parameters related to mineral tissue accumulation and biomass accumulation, except for germination percentage, shoot fresh weight, N, P, Ca, Mg, and S in roots and shoots of both cultivars. These parameters were analyzed taking the $\mathrm{F}$ test into consideration, also for individual effects of either $\mathrm{NaCl}$ or $\mathrm{K}$ doses. Because there was no significant effect of $\mathrm{K}$ dose, but there was of $\mathrm{Na}$ dose (salinity), the results are presented for salinity inside of each $\mathrm{K}$ dose.

\section{Results}

\subsection{Effect of Combined Salinity and Potassium Doses on Germination and Seedling Establishment}

There was no effect of $\mathrm{K}$ dose or significant interaction between $\mathrm{Na}$ and $\mathrm{K}$ doses but there was a significant effect of salinity on both germination and shoot fresh weight. During germination and seedling establishment, there was a significant decrease in the percentage of germination (GP) and in the coefficient of velocity of germination (CVG) with increased $\mathrm{NaCl}$-induced salinity for both cultivars, regardless of the $\mathrm{K}$ dose. Thus, results were presented in terms of nominal $\mathrm{NaCl}$ doses (Figure 1), calling attention to the fact that $\mathrm{Cl}^{-}$concentrations, after the control, increased in parallel with $\mathrm{Na}^{+}$in irrigation waters. At high $\mathrm{NaCl}$ doses, GP decreased for both cultivars. However, the GP of 'Raccoon' was significantly better than control $\left(5 \mathrm{mmol}_{\mathrm{C}} \mathrm{L}^{-1}\right)$ at $60 \mathrm{mmol}_{\mathrm{C}} \mathrm{L}^{-1}$, both at 22 and 32 days after seeding, while 'Gazelle' maintained GP up to $60 \mathrm{mmol}_{\mathrm{c}} \mathrm{L}^{-1}$ at 13 days and up to $120 \mathrm{mmol}_{\mathrm{c}} \mathrm{L}^{-1}$ 
at 32 days after germination (Figure 1). The CVG decreased significantly with $\mathrm{NaCl}$ dose for both cultivars, with the decrease more pronounced in 'Raccoon' than 'Gazelle', which maintained its CVG level up to $60 \mathrm{mmol}_{\mathrm{c}} \mathrm{L}^{-1}$.
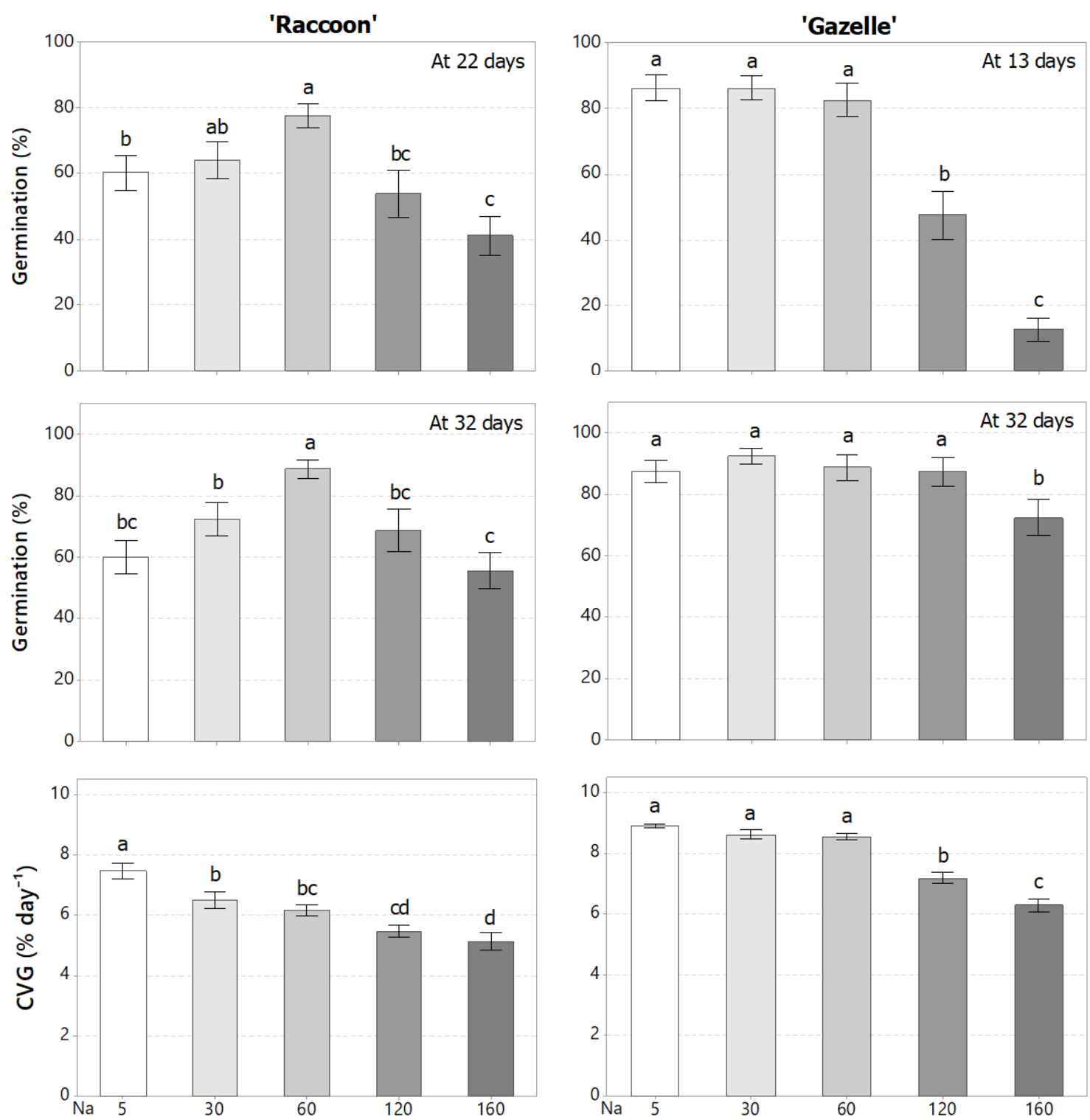

Figure 1. Germination percentage (\%) for initial germination count and at 32 days and coefficient of velocity of germination (CVG) for 'Raccoon' and 'Gazelle' for different doses of $\mathrm{NaCl}(\mathrm{Na})$ in $\mathrm{mmol}_{\mathrm{C}} \mathrm{L}^{-1}$. Mean bars with different letters are significantly different by Fisher's LSD test $(p<0.05)$. Interval bars represent the standard errors of means. Lowercase letters: compare $\mathrm{NaCl}$ doses $(\mathrm{Na})$ for germination parameters inside each cultivar. Because there was no effect of $\mathrm{K}$ doses, samples were grouped per salinity treatment, with $n=16$.

Seedling shoot fresh weight decreased for both cultivars as salinity increased (Figure 2), regardless of $\mathrm{K}$ dose. However, after 32 days of irrigation with high-salinity water, seedlings had no visual signs of $\mathrm{NaCl}$ toxicity (Figure 2). 

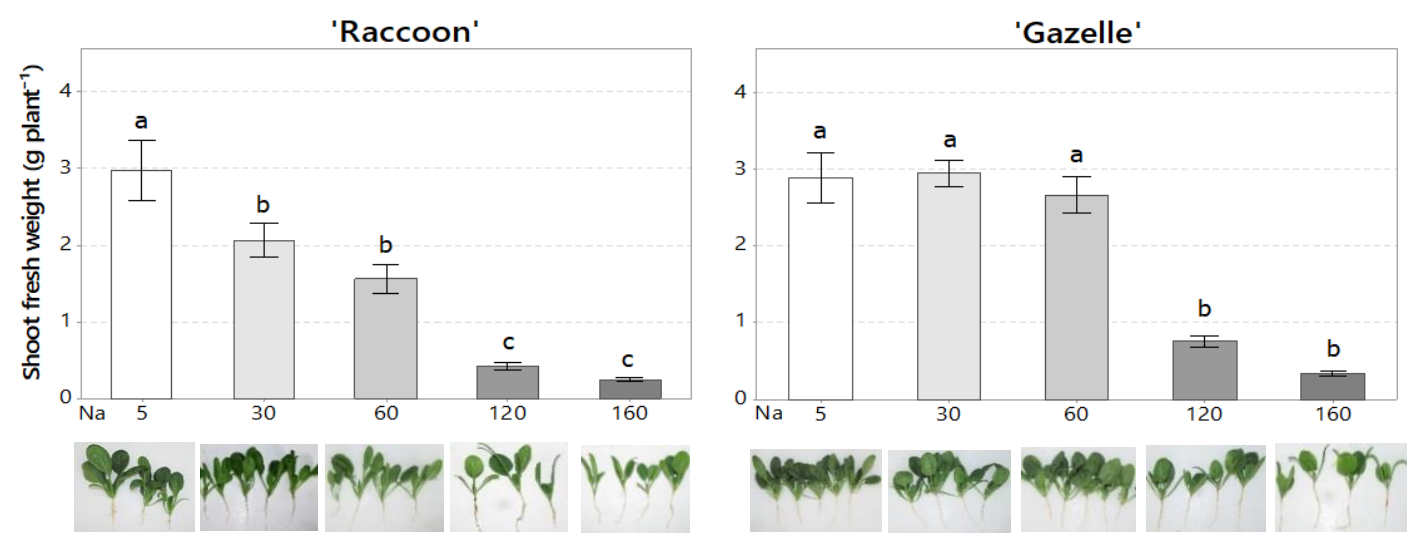

Figure 2. Seedling shoot fresh weight and appearance of 'Raccoon' and 'Gazelle' seedlings at different $\mathrm{NaCl}(\mathrm{Na})$ doses in $\mathrm{mmol}_{\mathrm{C}} \mathrm{L}^{-1}$, regardless of $\mathrm{KCl}$ dose $(n=16)$. Mean bars with different letters are significantly different by Fisher's LSD test $(p<0.05)$. Interval bars show standard errors of means. Plants pictured are from one random pot with $3.0 \mathrm{mmol}_{\mathrm{C}} \mathrm{L}^{-1} \mathrm{~K}$ at each Na dose.

\subsection{Effect of Combined Salinity and Potassium Doses on Tissue $\mathrm{Na}$ and $\mathrm{Cl}$ Accumulation}

A second experiment was conducted with seedlings of 6-8 true leaves submitted to the same $\mathrm{NaCl}$ concentrations and potassium doses (three deficient and one control) used in the germination study. From here on, all the results are related to this second experiment. The effects of increased $\mathrm{NaCl}$ on tissue ionic composition were evaluated through the tissue accumulation of $\mathrm{Na}$ and $\mathrm{Cl}$ in root and shoot tissues of 'Raccoon' and 'Gazelle' (Figure 3). In general, both Na and $\mathrm{Cl}$ increased with every increase in irrigation-water salinity with both ions accumulating at similar concentrations in roots but with $\mathrm{Cl}$ accumulating at higher concentrations in shoots than $\mathrm{Na}$ (Figure 3). In roots, from control to the highest salinity treatment, both cultivars showed similar increases of 2-fold for $\mathrm{Na}$ (from 13 to $26 \mathrm{~g} \mathrm{~kg}^{-1}$, approximately) and 5.6-fold for $\mathrm{Cl}$ (from 4.5 to $25 \mathrm{~g} \mathrm{~kg}^{-1}$, approximately). In shoots, from control to the highest salinity treatment, the accumulation of $\mathrm{Na}$ and $\mathrm{Cl}$ in 'Gazelle' (Figure 3) was similar to that of 'Raccoon' and was approximately 3-fold for $\mathrm{Na}$ and from 7.6 ('Raccoon') to 9.0 ('Gazelle') times higher for $\mathrm{Cl}$ from control to $160 \mathrm{mmol}_{\mathrm{C}} \mathrm{L}^{-1} \mathrm{NaCl}$, regardless of $\mathrm{K}$ doses (Figure 3).

For both cultivars the Na:K ratio increased with increased salinity but decreased significantly when $\mathrm{K}$ dose increased from deficient $\left(0.07-0.3 \mathrm{mmol}_{\mathrm{c}} \mathrm{L}^{-1}\right)$ to sufficient $\left(3.0 \mathrm{mmol}_{\mathrm{C}} \mathrm{L}^{-1}\right)$. Although the decrease lessened at higher $\mathrm{NaCl}$ doses, it was still significant for shoots of 'Raccoon' and for roots and shoots of 'Gazelle' (Figure 4). At control salinity $\left(5 \mathrm{mmol}_{\mathrm{c}} \mathrm{L}^{-1} \mathrm{NaCl}\right)$ the decrease in $\mathrm{Na}: \mathrm{K}$ ratio in shoots was seen stepwise, mainly for 'Gazelle', despite the low increase in K concentration for deficient doses. At higher salinities, this decrease in Na:K ratio was only observed when $\mathrm{K}$ dose increased from deficient to $3.0 \mathrm{mmol}_{\mathrm{C}} \mathrm{L}^{-1}$ (Figure 4).

\subsection{Effect of Combined Salinity and Potassium Doses on Root Mineral Composition}

The effects of combined increased $\mathrm{NaCl}$ with potassium deficiency was evaluated on root and shoot composition of macronutrients (Table 3) and micronutrients (Supplementary Tables S1 and S2). Despite the significant increase in both $\mathrm{Na}$ and $\mathrm{Cl}$, roots maintained their concentrations of $\mathrm{K}$ (14.3 to $26.8 \mathrm{~g} \mathrm{~kg}^{-1}$ for 'Raccoon' and 15.0 to $28.3 \mathrm{~g} \mathrm{~kg}^{-1}$ for 'Gazelle') (Figure 5) and of N (18.6 to $25.2 \mathrm{~g} \mathrm{~kg}^{-1}$ for both cultivars), even when $\mathrm{K}$ was applied at deficient doses (Table 3). However, $\mathrm{Ca}, \mathrm{Mg}$, and $\mathrm{S}$ decreased significantly with salinity by approximately $50 \%, 32 \%$, and $54 \%$, respectively, in roots of both cultivars (Table 3). Interestingly, P increased significantly with salinity, in each $\mathrm{K}$ dose, in roots of 'Gazelle'. However, the increase was not always significant in roots of 'Raccoon' (Table 3). 

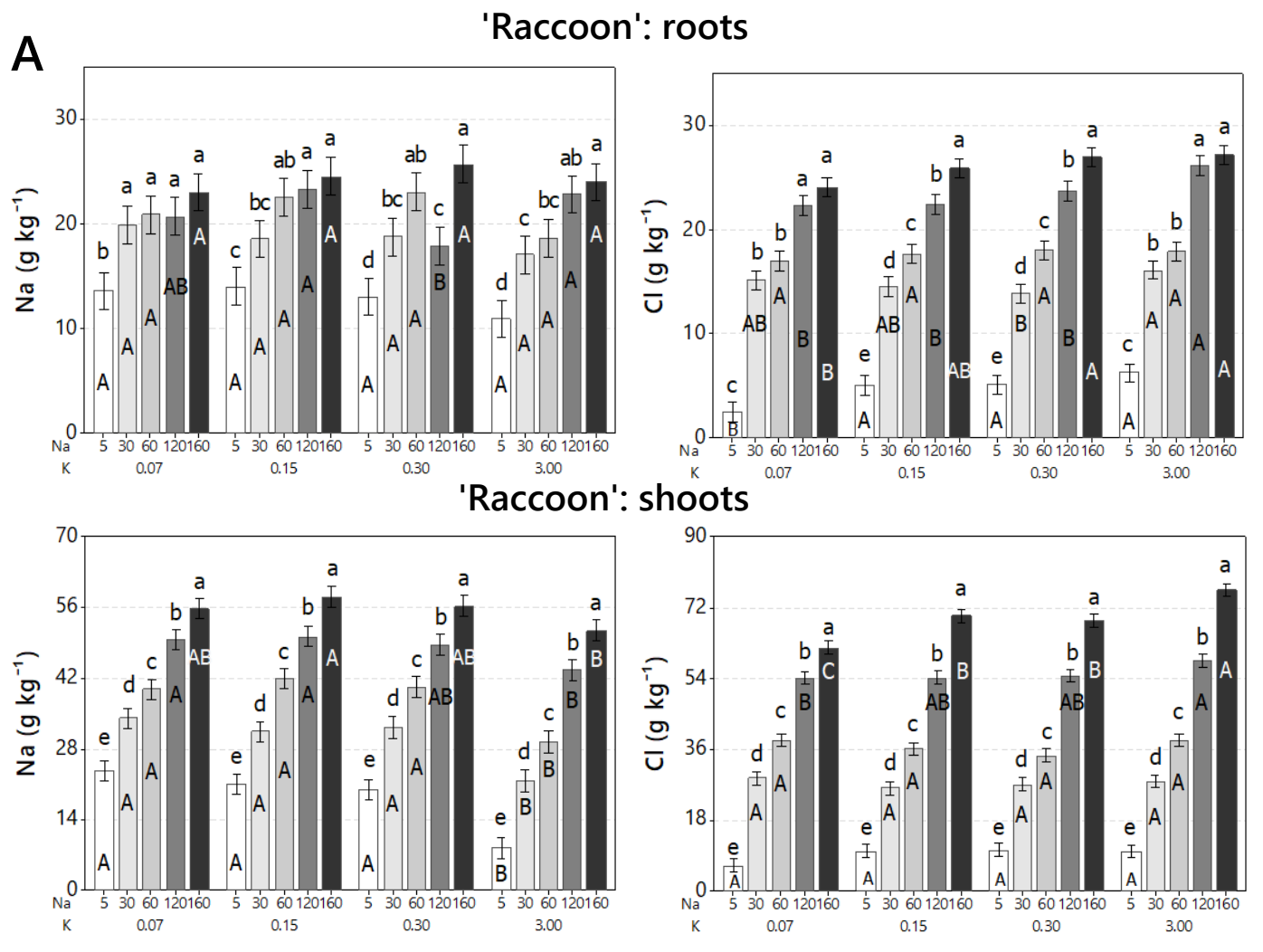

B

'Gazelle': roots
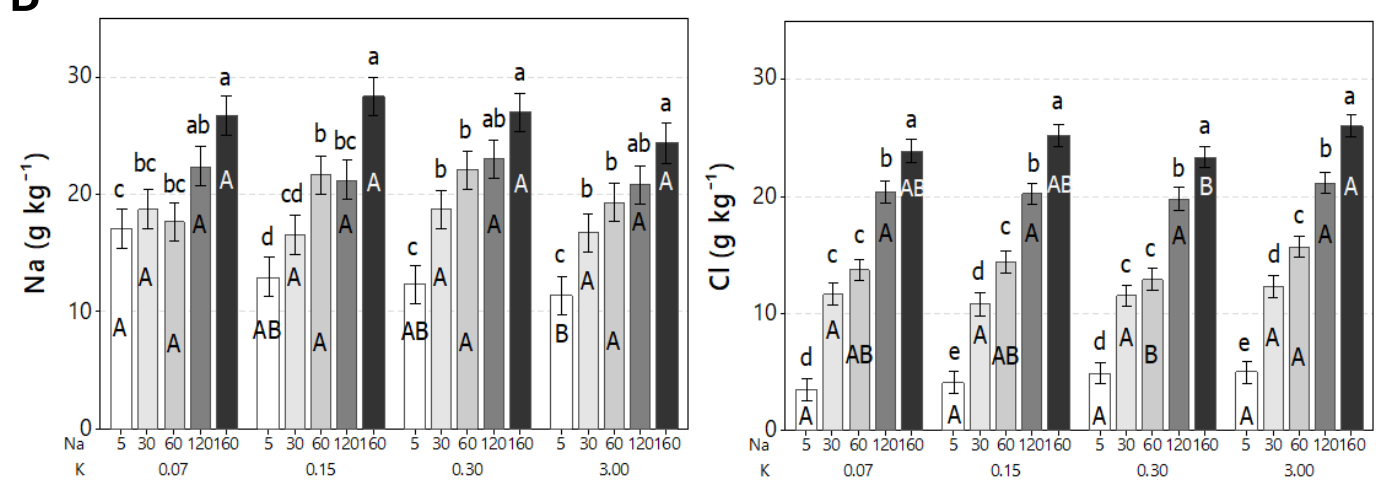

'Gazelle': shoots
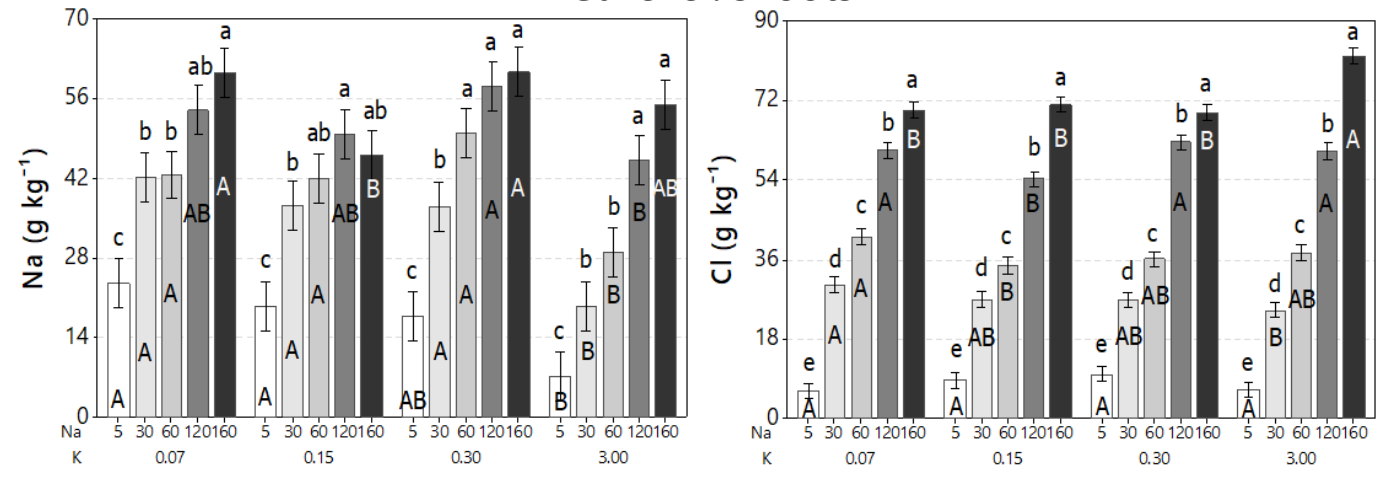

Figure 3. Concentrations of $\mathrm{Na}$ and $\mathrm{Cl}$ in roots and shoots of 'Raccoon' (A) and 'Gazelle' (B) for the respective combinations of $\mathrm{NaCl}(\mathrm{Na})$ and $\mathrm{KCl}(\mathrm{K})$ doses. Mean bars with different letters are significantly different by Fisher's LSD test $(p<0.05)$. Interval bars show standard errors of means. Uppercase letters compare $\mathrm{K}$ doses within each $\mathrm{Na}$, inside each mineral. Lowercase letters compare $\mathrm{NaCl}$ doses $(\mathrm{Na})$, within each $\mathrm{K}$ dose, for either $\mathrm{Na}$ or $\mathrm{Cl}$. 

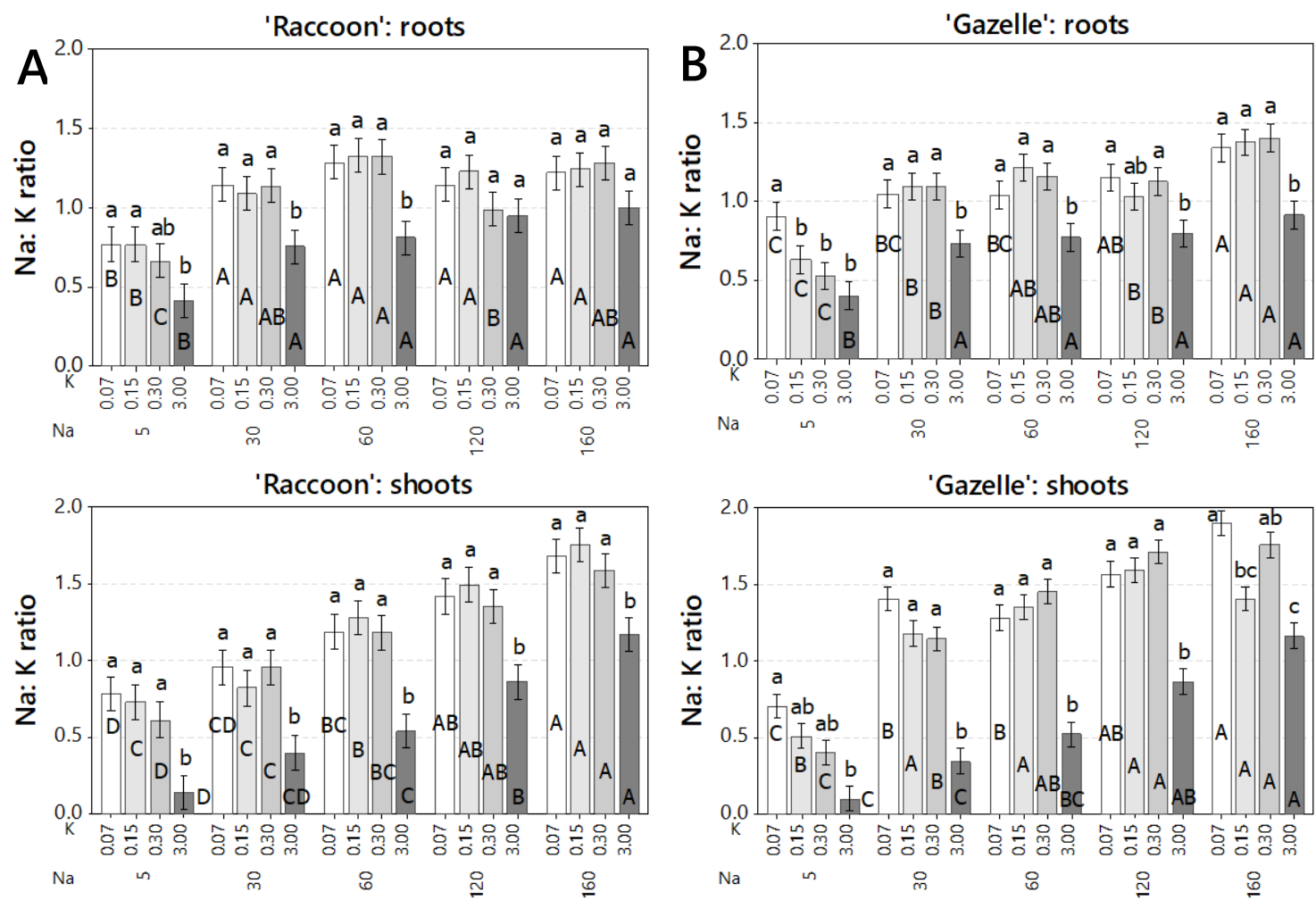

Figure 4. Na:K ratio in roots and shoots of 'Raccoon' (A) and 'Gazelle' (B) for the respective combinations of $\mathrm{KCl}(\mathrm{K})$ and $\mathrm{NaCl}(\mathrm{Na})$ doses $\left(\mathrm{mmol}_{\mathrm{C}} \mathrm{L}^{-1}\right)$. Mean bars with different letters are significantly different by Fisher's LSD test $(p<0.05)$. Interval bars show standard errors of means. Uppercase letters compare $\mathrm{NaCl}(\mathrm{Na})$ doses, within each $\mathrm{K}$ dose, inside organ and cultivar. Lowercase letters compare K doses, within each $\mathrm{Na}$ dose, inside organ and cultivar.

Table 3. Mean concentrations of macronutrients in roots and shoots of 'Raccoon' and 'Gazelle' for the respective doses of $\mathrm{NaCl}$ (5.00 to $160.00 \mathrm{mmol}_{\mathrm{C}} \mathrm{L}^{-1}$ ) pooled for all $\mathrm{KCl}$ doses due to lack of $\mathrm{K}$ effect $(n=16)$.

\begin{tabular}{|c|c|c|c|c|c|c|c|c|c|c|}
\hline \multirow{3}{*}{ Nutrient } & \multicolumn{5}{|c|}{ Roots } & \multicolumn{5}{|c|}{ Shoots } \\
\hline & \multicolumn{10}{|c|}{$\mathrm{NaCl}$ Doses $\left(\mathrm{mmol}_{\mathrm{c}} \mathrm{L}^{-1}\right)$} \\
\hline & 5.0 & 30.0 & 60.0 & 120.0 & 160.0 & 5.0 & 30.0 & 60.0 & 120.0 & 160.0 \\
\hline & \multicolumn{10}{|c|}{ 'Raccoon' } \\
\hline $\mathbf{N}(\%)$ & $2.42 \mathrm{~A}$ & $2.10 \mathrm{~B}$ & $2.19 \mathrm{~B}$ & $2.17 \mathrm{~B}$ & $2.35 \mathrm{~A}$ & $4.82 \mathrm{~A}$ & $4.50 \mathrm{C}$ & $4.61 \mathrm{BC}$ & $4.65 \mathrm{ABC}$ & $4.70 \mathrm{AB}$ \\
\hline $\mathbf{P}\left(\mathrm{g} \mathrm{kg}^{-1}\right)$ & $4.96 \mathrm{~B}$ & $4.86 \mathrm{~B}$ & $5.41 \mathrm{AB}$ & $5.38 \mathrm{~B}$ & $5.95 \mathrm{~A}$ & $4.88 \mathrm{AB}$ & $4.74 \mathrm{~B}$ & $4.88 \mathrm{~B}$ & $4.92 \mathrm{AB}$ & $5.17 \mathrm{~A}$ \\
\hline $\mathrm{Ca}\left(\mathrm{g} \mathrm{kg}^{-1}\right)$ & $9.01 \mathrm{~A}$ & $7.33 \mathrm{~B}$ & $6.27 \mathrm{C}$ & $4.28 \mathrm{D}$ & $4.49 \mathrm{D}$ & $15.21 \mathrm{~A}$ & $10.09 \mathrm{~B}$ & $7.56 \mathrm{C}$ & $7.11 \mathrm{C}$ & $7.03 \mathrm{C}$ \\
\hline $\operatorname{Mg}\left(\mathrm{g} \mathrm{kg}^{-1}\right)$ & $11.50 \mathrm{~A}$ & $9.74 \mathrm{~B}$ & $8.65 \mathrm{C}$ & $6.73 \mathrm{D}$ & $7.59 \mathrm{D}$ & $10.95 \mathrm{~A}$ & $9.78 \mathrm{~B}$ & $8.84 \mathrm{C}$ & $7.88 \mathrm{D}$ & $7.55 \mathrm{D}$ \\
\hline \multirow[t]{2}{*}{$\mathbf{S}\left(\mathrm{g} \mathrm{kg}^{-1}\right)$} & $5.36 \mathrm{~A}$ & $3.78 \mathrm{~B}$ & $3.49 \mathrm{~B}$ & $2.11 \mathrm{C}$ & $2.39 \mathrm{C}$ & $4.98 \mathrm{~A}$ & $4.32 \mathrm{~B}$ & $4.06 \mathrm{C}$ & $3.44 \mathrm{D}$ & $3.24 \mathrm{D}$ \\
\hline & \multicolumn{10}{|c|}{ 'Gazelle' } \\
\hline $\mathbf{N}(\%)$ & $2.27 \mathrm{AB}$ & $2.02 \mathrm{D}$ & $2.09 \mathrm{CD}$ & $2.23 \mathrm{BC}$ & $2.42 \mathrm{~A}$ & $3.94 \mathrm{~A}$ & $3.60 \mathrm{~A}$ & $3.47 \mathrm{~A}$ & $3.61 \mathrm{~A}$ & $3.97 \mathrm{~A}$ \\
\hline $\mathbf{P}\left(\mathrm{g} \mathrm{kg}^{-1}\right)$ & $5.32 \mathrm{CD}$ & $5.08 \mathrm{D}$ & $5.78 \mathrm{BC}$ & $6.17 \mathrm{AB}$ & $6.62 \mathrm{~A}$ & $4.57 \mathrm{BC}$ & $4.31 \mathrm{C}$ & $4.58 \mathrm{~B}$ & $4.60 \mathrm{~B}$ & $5.04 \mathrm{~A}$ \\
\hline $\mathrm{Ca}\left(\mathrm{g} \mathrm{kg}^{-1}\right)$ & $8.52 \mathrm{~A}$ & $6.68 \mathrm{~B}$ & $5.89 \mathrm{C}$ & $4.52 \mathrm{D}$ & $4.20 \mathrm{D}$ & $10.90 \mathrm{~A}$ & $7.64 \mathrm{~B}$ & $6.30 \mathrm{C}$ & $5.45 \mathrm{D}$ & $5.04 \mathrm{D}$ \\
\hline $\operatorname{Mg}\left(\mathrm{g} \mathrm{kg}^{-1}\right)$ & $10.62 \mathrm{~A}$ & $8.85 \mathrm{~B}$ & $8.29 \mathrm{~B}$ & $7.48 \mathrm{C}$ & $7.57 \mathrm{C}$ & $9.71 \mathrm{~A}$ & $8.32 \mathrm{~B}$ & $8.10 \mathrm{~B}$ & $7.32 \mathrm{C}$ & $6.94 \mathrm{C}$ \\
\hline $\mathbf{S}\left(\mathrm{g} \mathrm{kg}^{-1}\right)$ & $4.82 \mathrm{~A}$ & $3.59 \mathrm{~B}$ & $3.33 \mathrm{~B}$ & $2.60 \mathrm{C}$ & $2.31 \mathrm{C}$ & $4.40 \mathrm{~A}$ & $4.00 \mathrm{~B}$ & $3.79 \mathrm{~B}$ & $3.29 \mathrm{C}$ & $3.11 \mathrm{C}$ \\
\hline
\end{tabular}

Means with different letters are significantly different by Fisher's LSD test $(p<0.05)$. Uppercase letters: comparisons between $\mathrm{NaCl}$ doses, within each cultivar. 

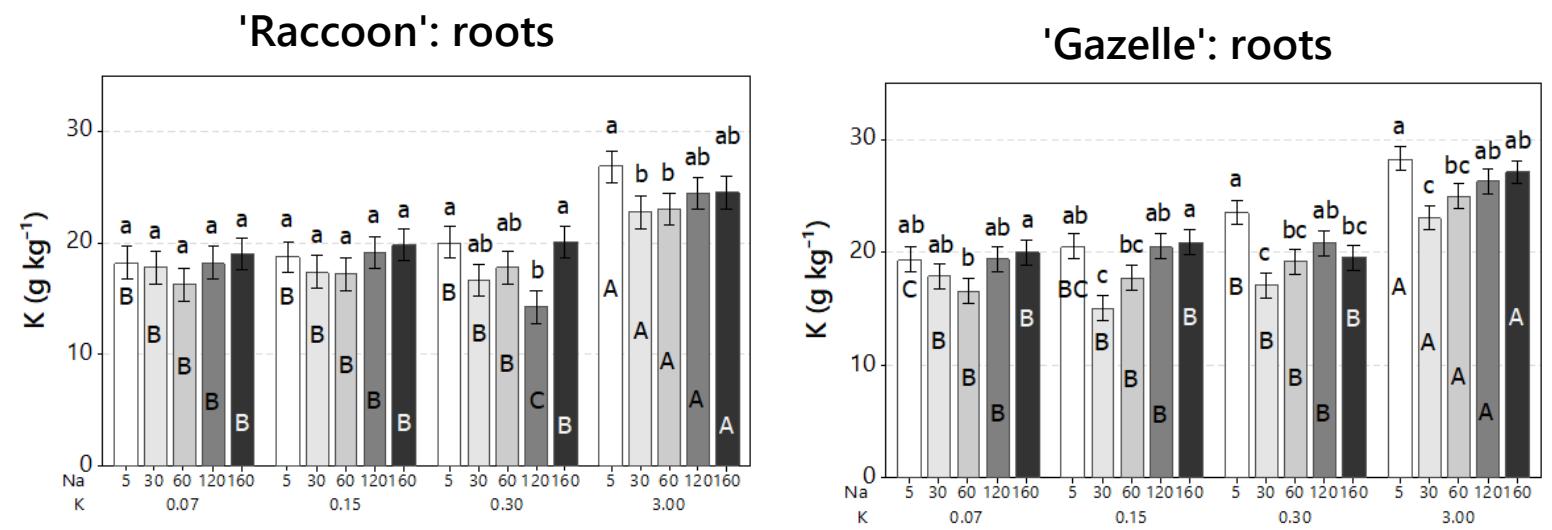

Figure 5. Concentrations of potassium in roots of 'Raccoon' (left) and 'Gazelle' (right) for the respective combinations of $\mathrm{NaCl}(\mathrm{Na})$ (from 5 to $160 \mathrm{mmol}_{\mathrm{C}} \mathrm{L}^{-1}$ ), and $\mathrm{KCl}(\mathrm{K})$ doses (from 0.07 to $\left.3.0 \mathrm{mmol}_{\mathrm{C}} \mathrm{L}^{-1}\right)$. Mean bars with different letters are significantly different by Fisher's LSD test $(p<0.05)$. Interval bars show standard errors of means. Lowercase letters compare Na doses within each $\mathrm{K}$ dose. Uppercase letters compare $\mathrm{K}$ doses within each $\mathrm{Na}$ dose.

Regarding root micronutrients, 'Raccoon' Fe was the highest, ranging from 820 (highest salinity) to $1350 \mathrm{mg} \mathrm{kg}^{-1}$ (control salinity), followed by Mn, which ranged from 254 (highest salinity) to $304 \mathrm{mg} \mathrm{kg}^{-1}$ (control salinity), with the remaining micronutrients $(\mathrm{B}, \mathrm{Cu}$, and $\mathrm{Zn}$ ) ranging from 19 to $29.7 \mathrm{mg} \mathrm{kg}^{-1}$. Salinity increase led to a significant reduction of $\mathrm{Cu}(35 \%), \mathrm{Fe}(39 \%)$, and $\mathrm{Mn}(16.5 \%)$ but had no effect of the concentrations of B (18-24 mg kg${ }^{-1}$ ) or Zn (22 to $29.7 \mathrm{mg} \mathrm{kg}^{-1}$ ) (Table S1). In 'Gazelle', $\mathrm{Fe}$ and Mn were also the highest micronutrients ranging, respectively, from 975 to $1730 \mathrm{mg} \mathrm{kg}^{-1}$ and from 250 to $452 \mathrm{mg} \mathrm{kg}^{-1}$, while B ranged from $40-50 \mathrm{mg} \mathrm{kg}^{-1}$ and $\mathrm{Zn}$ from $19-25 \mathrm{mg} \mathrm{kg}^{-1}$. Salinity led to significant reductions in $\mathrm{Cu}(50 \%), \mathrm{Fe}(44 \%), \mathrm{Mn}(43 \%)$, and $\mathrm{Zn}(24 \%)$ (Table S2).

\subsection{Effect of Combined Salinity and Potassium Doses on Shoot Mineral Composition}

Similar to roots, and regardless of the significant increases in $\mathrm{Na}$ and $\mathrm{Cl}$, or K-deficient doses, shoot concentrations of K (Figure 6) and N (Table 3) were maintained and ranged from 31.9 (when K was provided in deficient doses) to $61.6 \mathrm{~g} \mathrm{~kg}^{-1}$ (when $\mathrm{K}$ was provided at $3.0 \mathrm{mmol}_{\mathrm{C}} \mathrm{L}^{-1}$ ) for 'Raccoon' and from 30.5 (deficient $\mathrm{K}$ ) to $73.5 \mathrm{~g} \mathrm{~kg}^{-1}\left(3.0 \mathrm{mmol}_{\mathrm{C}} \mathrm{L}^{-1} \mathrm{~K}\right.$ ) for 'Gazelle', while $\mathrm{N}$ ranged from 43.4 to $49.3 \mathrm{~g} \mathrm{~kg}^{-1}$ for 'Raccoon' (Figure 6, left, Table 3) and from 28.5 to $42.0 \mathrm{~g} \mathrm{~kg}^{-1}$ for 'Gazelle' (Figure 6, right, Table 3). As observed in roots, $\mathrm{P}$ was maintained or slightly increased (at high $\mathrm{NaCl}$ doses), while $\mathrm{Ca}, \mathrm{Mg}$, and $\mathrm{S}$ decreased with salinity in 54\%, 31\%, and 36\%, respectively for 'Raccoon' and 53\%, $29 \%$, and $29.5 \%$, respectively for 'Gazelle' (Table 3). When K was provided at the sufficient dose of $3.0 \mathrm{mmol}_{\mathrm{C}} \mathrm{L}^{-1}$, there was a significant decrease in shoot $\mathrm{K}$ of both cultivars when salinity increased beyond control salinity and mainly from control to the highest salinity, with an average K decrease of $31 \%$ for 'Raccoon' and 34\% for 'Gazelle' (Figure 6).

Like root micronutrient concentration, Fe and Mn were the highest micronutrients found in shoots of both cultivars without a trend in their concentration associated with salinity or K dose (Tables S1 and S2).

\subsection{Effect of Combined Salinity and Potassium Doses on Plant Biomass Accumulation}

Salinity effects were evaluated on plant vegetative growth and biomass accumulation through plant appearance (Figure 7), RDW, and SDW (Figure 8). Although salinity caused significant reductions in the concentrations of $\mathrm{Ca}, \mathrm{Mg}$, and $\mathrm{S}$, these reductions were not enough to cause visual mineral deficiencies, regardless of $\mathrm{K}$ and $\mathrm{NaCl}$ doses, and allowed the development of healthy-looking spinach plants (Figure 7). 
'Raccoon': shoots

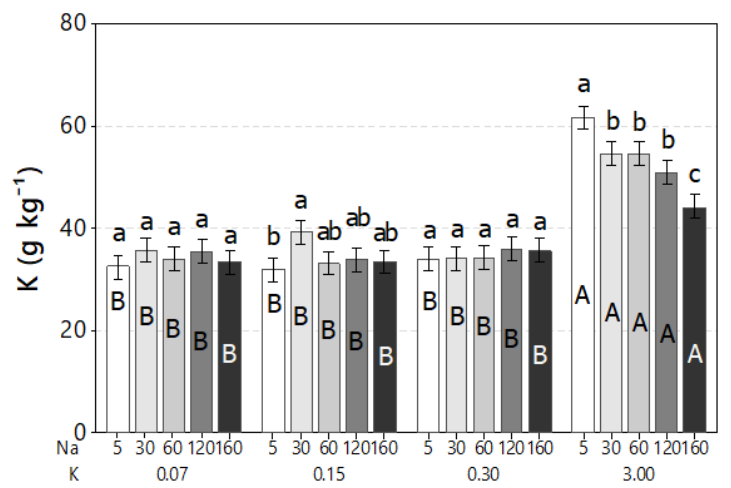

'Gazelle': shoots

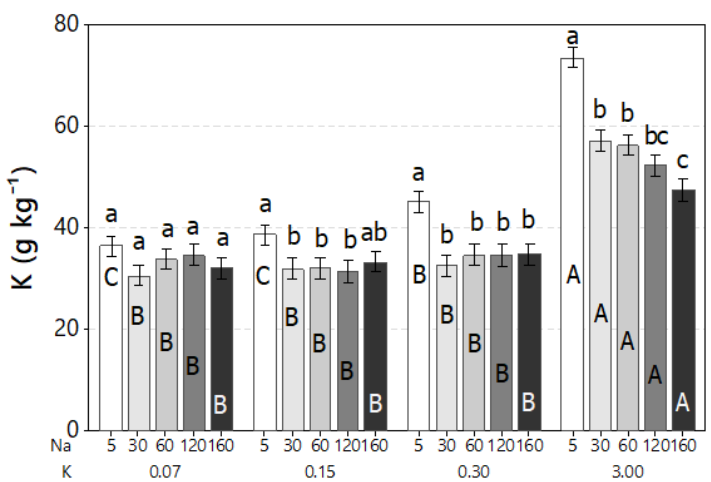

Figure 6. Concentrations of the mineral potassium $\left(\mathrm{K}\right.$, in $\left.\mathrm{g} \mathrm{kg}^{-1}\right)$ in shoots for 'Raccoon' (left) and 'Gazelle' (right) for the respective combinations of $\mathrm{NaCl}\left(\mathrm{Na}\right.$ ) (from 5.0 to $160.0 \mathrm{mmol}_{\mathrm{C}} \mathrm{L}^{-1}$ ) and $\mathrm{KCl}$ $(\mathrm{K})$ doses (from 0.07 to $3.0 \mathrm{mmol}_{\mathrm{C}} \mathrm{L}^{-1}$ ). Mean bars with different letters are significantly different by Fisher's LSD test $(p<0.05)$. Interval bars show standard errors of means. Uppercase letters compare $\mathrm{K}$ within each $\mathrm{Na}$ dose in shoots of each cultivar. Lowercase letters compare $\mathrm{Na}$ doses, within each $\mathrm{K}$ dose.

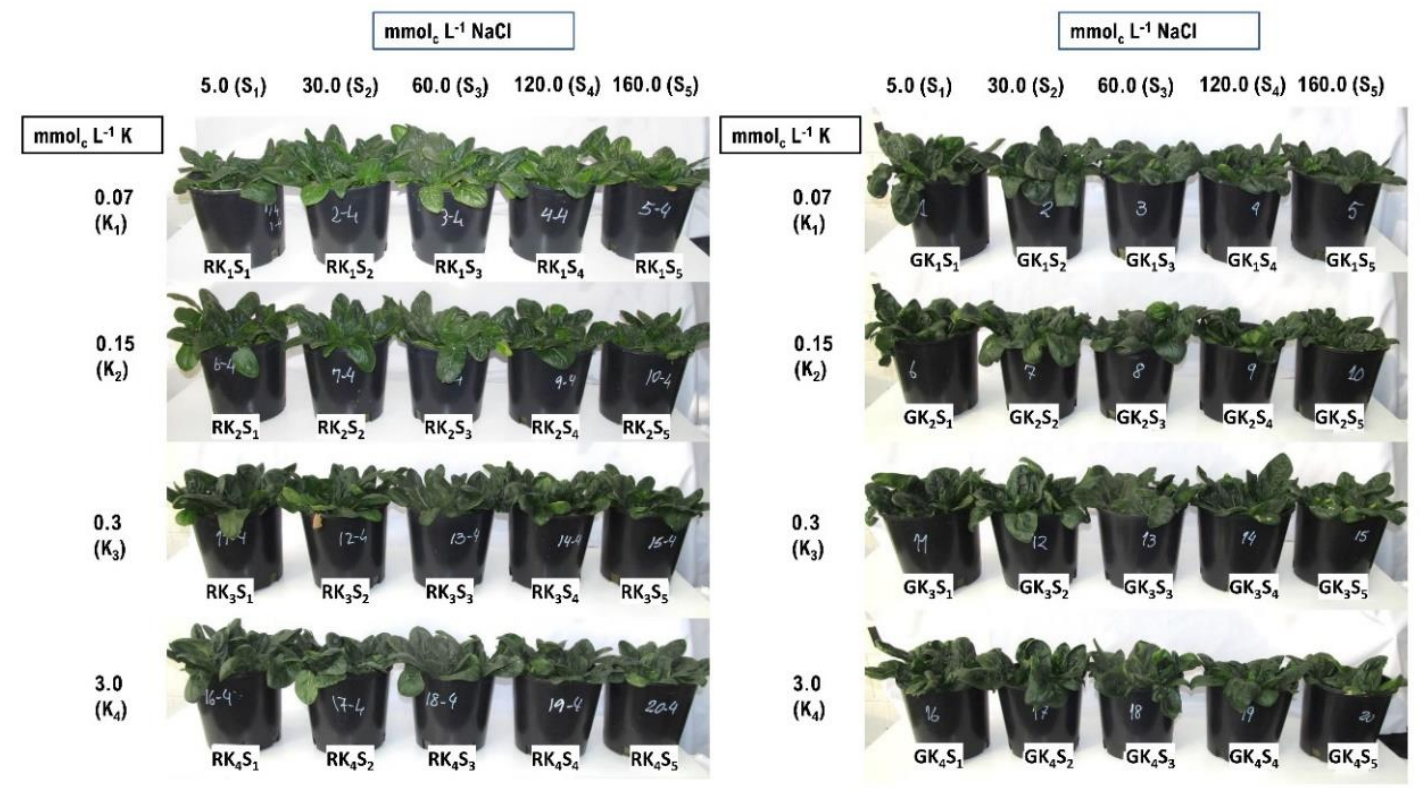

Figure 7. Appearance of spinach plants for 'Raccoon' (R, left) and' ( $G$, right) seven weeks (50 days) after treatments with the respective combinations of $\mathrm{NaCl}\left(5.0\right.$ to $\left.160.0 \mathrm{mmol}_{\mathrm{C}} \mathrm{L}^{-1}\right)$, or salinity treatments $\mathrm{S}_{1}$ to $\mathrm{S}_{5}$ and potassium, as potassium chloride $(\mathrm{KCl})$ or $\mathrm{K}\left(0.07\right.$ to $\left.3.0 \mathrm{mmol}_{\mathrm{c}} \mathrm{L}^{-1}\right)$ doses $\mathrm{K}_{1}$ to $\mathrm{K}_{4}$. Plants were photographed the same day the experiment was terminated.

Regarding K dose, 'Raccoon' plants had a significant increase in shoot biomass when K increased from $0.07 \mathrm{mmol}_{\mathrm{C}} \mathrm{L}^{-1}$ to higher $\mathrm{K}$ doses. 'Gazelle' had a similar response, although significant shoot biomass increase was only significant for the $\mathrm{K}$ doses of 0.3 and $3.0 \mathrm{mmol}_{\mathrm{C}} \mathrm{L}^{-1}$. However, $\mathrm{K}$ doses higher than $0.07 \mathrm{mmol}_{\mathrm{C}} \mathrm{L}^{-1}$ had no effect on biomass of either cultivar when $\mathrm{NaCl}$ doses were higher than $30 \mathrm{mmol}_{\mathrm{C}} \mathrm{L}^{-1}$ (Figure 8). For SDW, at the lowest $\mathrm{K}$ dose of $0.07 \mathrm{mmol}_{\mathrm{C}} \mathrm{L}^{-1}$, plants of both cultivars increased SDW significantly when Na concentration increased from 5.0 to 30 and $60 \mathrm{mmol}_{\mathrm{C}} \mathrm{L}^{-1}$. The average SDW ranged from 7.9 to $10.4 \mathrm{~g} \mathrm{pot}^{-1}$ for 'Raccoon' and from 8.2 to $10.6 \mathrm{~g} \mathrm{pot}^{-1}$ for 'Gazelle' and, when there was a significant increase or decrease in SDW, the difference was approximately $2.0 \mathrm{~g} \mathrm{pot}^{-1}$ (Figure 8). Although K doses had little or no effect on root dry weight (RDW) and shoot dry 
weight (SDW), RDW of 'Gazelle' increased significantly at $30 \mathrm{mmol}_{\mathrm{c}} \mathrm{L}^{-1} \mathrm{NaCl}$ when $\mathrm{K}$ was sufficient ( $3.0 \mathrm{mmol}_{\mathrm{C}} \mathrm{L}^{-1}$ ). The data showed a similar increase for 'Raccoon' at the same $\mathrm{NaCl}$ dose (although not significant) as if a small increase in salinity had favored root development (Figure 8).
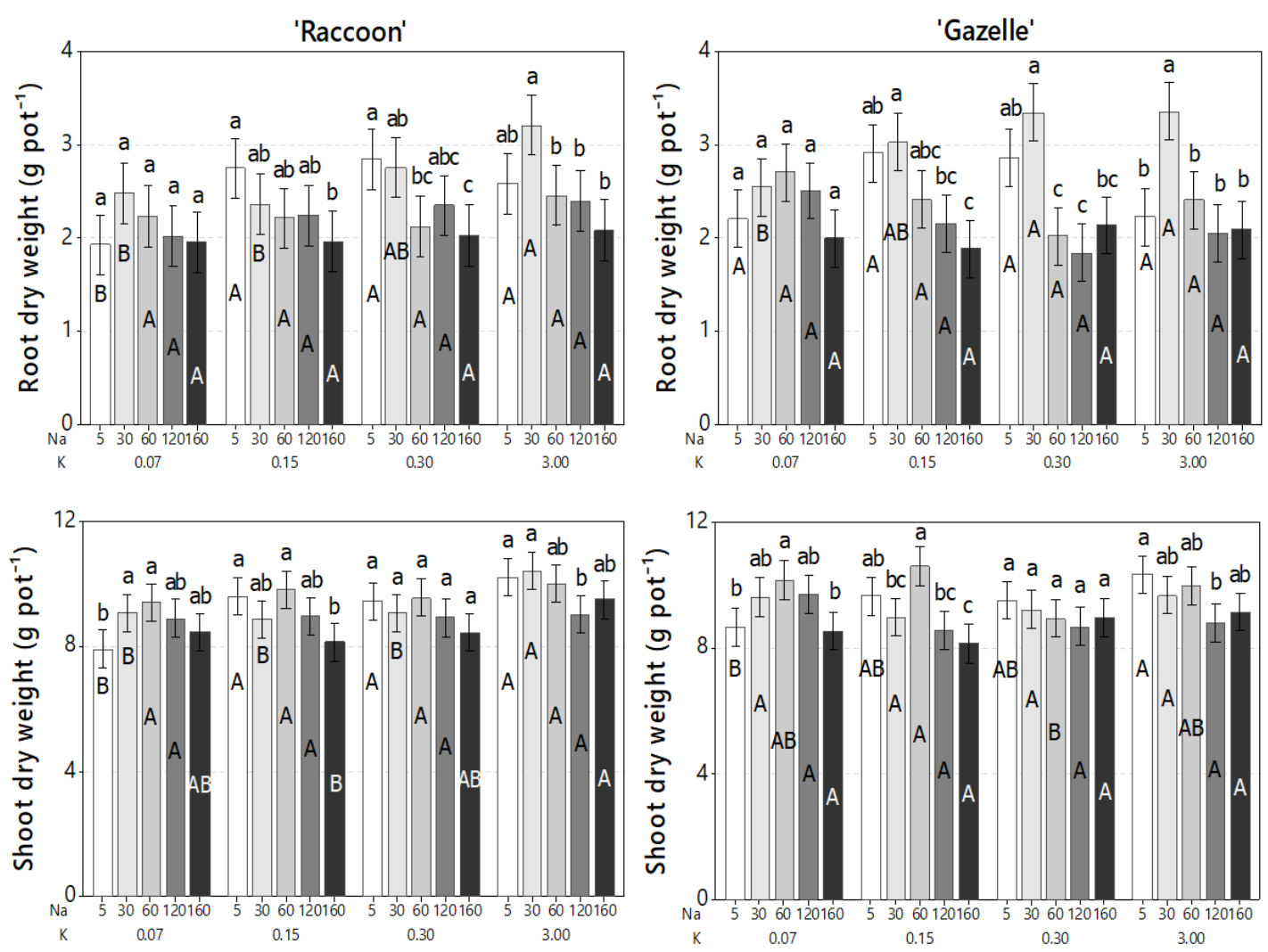

Figure 8. Dry biomass of roots and shoots for 'Raccoon' and 'Gazelle' for the respective combinations of $\mathrm{NaCl}(\mathrm{Na})$ and $\mathrm{KCl}(\mathrm{K})$ doses in $\mathrm{mmol}_{\mathrm{C}} \mathrm{L}^{-1}$. Mean bars with different letters are significantly different by Fisher's LSD test $(p<0.05)$. Interval bars show standard errors of means. Uppercase letters compare $\mathrm{K}$ doses within each $\mathrm{Na}$ dose, for roots or shoots inside each cultivar. Lowercase letters compare $\mathrm{Na}$ doses, within each $\mathrm{K}$ dose, for roots or shoots inside each cultivar.

\section{Discussion}

\subsection{Effect of Combined Salinity and Potassium Doses on Germination and Seedling Establishment}

While there was no effect of $\mathrm{K}$ dose on germination, 'Raccoon' had its germination improved by salinity while 'Gazelle' was more tolerant to salinity than 'Raccoon' during germination and seedling establishment. Different researchers cited in the introduction demonstrated that crop germination decreased with increased salinity of irrigation water. The salinity threshold of approximately $120 \mathrm{mmol}_{\mathrm{C}} \mathrm{L}^{-1} \mathrm{NaCl} 32$ days after germination for 'Gazelle' (Figure 1) was higher than that obtained for other cultivars of spinach such as 'Green Gold', 'Larisa', 'Mikado', and 'Ohio', in which the GP and relative germination rate were unaffected up to $50 \mathrm{mM}\left(50 \mathrm{mmol}_{\mathrm{c}} \mathrm{L}^{-1}\right) \mathrm{NaCl}$ but decreased significantly at $100 \mathrm{mM} \mathrm{NaCl}$, and further at $200 \mathrm{mM} \mathrm{NaCl}$ [20]. Our germination data also indicate that GP improved from the first counting date for each cultivar (22 days for 'Raccoon' and 13 days for 'Gazelle') to the last counting at 32 days after seeding (Figure 1). Because most of 'Gazelle' seeds germinated before 'Raccoon's seeds, CVG values for Gazelle were higher than those for 'Raccoon'. Although not compared statistically, mean GP and CVG for 'Gazelle' appeared to be better than those of 'Raccoon'. Average seedling fresh weight (Figure 2) also indicates that 'Gazelle' has a higher salinity tolerance than 'Raccoon'. Our data suggest that irrigation water salinity below $7.0 \mathrm{dS} \mathrm{m} \mathrm{m}^{-1}\left(60 \mathrm{mmol}_{\mathrm{c}} \mathrm{L}^{-1}\right)$ would not affect either GP or seedling growth of Gazelle (Figure 2) if irrigation frequency is enough 
to maintain soil salinity at similar levels of irrigation-water salinity. Although 'Gazelle' showed a better recuperation in GP than 'Raccoon', seedling fresh weight data (Figure 2) clearly indicated that seedling growth was significantly affected by $\mathrm{NaCl}$ doses above $60 \mathrm{mmol}_{\mathrm{c}} \mathrm{L}^{-1} \mathrm{NaCl}\left(7.0 \mathrm{dS} \mathrm{m} \mathrm{m}^{-1}\right)$. It has been previously shown that the lack of response to $\mathrm{K}$ fertilization at high levels of $\mathrm{NaCl}$ could be explained, at least in part, by the reduction in plant growth caused by $\mathrm{NaCl}$ ion toxicity, which limits the absorption of water and nutrients from the soil [46]. Although seedlings did not provide enough material for mineral analysis, they had no visual symptoms of either mineral deficiency or salt toxicity (Figure 2). Furthermore, because of 'Gazelle's CVG reflected a faster initial germination than that observed for 'Raccoon', seedling biomass observed for 'Gazelle' up to $60 \mathrm{mmol}_{\mathrm{C}} \mathrm{L}^{-1}$ may reflect the fact that 'Gazelle's seedlings had more time to adjust to salinity.

\subsection{Effect of Combined Salinity and Potassium Doses on Tissue Na and Cl Accumulation}

The significant increase in both $\mathrm{Na}$ and $\mathrm{Cl}$ in roots and shoots of both cultivars was expected with increasing $\mathrm{NaCl}$ concentrations. The steady and stepwise increase in tissue $\mathrm{Cl}$, which surpassed the increase in tissue $\mathrm{Na}$ (Figure 3), indicates that spinach is more efficient in controlling $\mathrm{Na}$ than $\mathrm{Cl}$. Increases in both tissue $\mathrm{Na}$ and $\mathrm{Cl}$ of similar magnitudes have been reported recently when irrigation water contained 90 and $120 \mathrm{mmol}_{\mathrm{C}} \mathrm{L}^{-1}$ of $\mathrm{NaCl}$ [8]. Interestingly, the use of saline water containing 120 and $160 \mathrm{mmol}_{\mathrm{C}} \mathrm{L}^{-1}$ in this study resulted in Na shoot accumulation of approximately $50-60 \mathrm{~g} \mathrm{~kg}^{-1}$, smaller than the $60-70 \mathrm{~g} \mathrm{~kg}^{-1}$ of shoot $\mathrm{Na}$ reported previously [8] for the same cultivars under 90 and $120 \mathrm{mmol}_{\mathrm{C}} \mathrm{L}^{-1}$ of $\mathrm{Na}$. The same can be said for $\mathrm{Cl}$. Our data indicate that spinach plants have control mechanisms triggered by salinity that allows plants to control salt tissue accumulation once $\mathrm{Na}$ and $\mathrm{Cl}$ reach a certain level. However, the salinity threshold beyond which the plant will no longer be able to control its tissue accumulation of $\mathrm{Na}$ and $\mathrm{Cl}$ has not been determined. It is noteworthy to mention that in naturally-saline waters, the concentration of $\mathrm{Cl}^{-}$can be as high to twice as high as the concentration of $\mathrm{Na}^{+}$.

The ratio of $\mathrm{Na}: \mathrm{K}$ is considered an important measure of tolerance of a species or cultivar to salinity. However, in the case of these two spinach cultivars, this ratio only increased with salinity because $\mathrm{Na}$ tissue levels increased significantly at every step while $\mathrm{K}$ tissue concentrations remained constant (Figures 5 and 6). However, the increase from 0.3 to $3.0 \mathrm{mmol}_{\mathrm{C}} \mathrm{L}^{-1}$ in $\mathrm{K}$ was enough to show that $\mathrm{K}$ tissue accumulation was antagonistic to $\mathrm{Na}$ tissue accumulation. These results agree with a previous report that concluded that a 20-fold increase in $\mathrm{K}$ from 0.25 to $5.0 \mathrm{mmol}_{\mathrm{C}} \mathrm{L}^{-1}$ decreased $\mathrm{Na}$ tissue accumulation [8].

\subsection{Effect of Combined Salinity and Potassium Doses on Root Mineral Composition}

Plants maintained adequate concentrations of N, P, and K in roots, regardless of salinity or K dose. Although $\mathrm{Ca}, \mathrm{Mg}$, and $\mathrm{S}$ decreased significantly with salinity, regardless of $\mathrm{K}$ dose, plants maintained a minimum concentration of these macronutrients needed for growth [8,47]. Root-P increase in both cultivars as salinity increased (Table 3) could have been an attempt for the plant to balance ions using $\mathrm{HPO}_{4}{ }^{2-}$ to compensate for a constant concentration of $\mathrm{NO}_{3}{ }^{-}$in the leaf (interpreted through the constant tissue levels of mineral $\mathrm{N}$ ), and in response to a steady increase of $\mathrm{Na}^{+}$in saline irrigation waters, as suggested by others [48]. Similar results were reported for 'Raccoon' and 'Gazelle' in previous salinity studies either when $\mathrm{K}$ was provided at sufficient doses [6] or when mineral composition was compared under salinity with $\mathrm{K}$ provided at both sufficient and deficient doses [8].

Regarding root micronutrients, Fe and Mn were the highest among other micronutrients tested. Although salinity significantly reduced Fe, Cu, and Mn (and Zn in 'Gazelle'), these micronutrients still were present at sufficient concentrations for root development. In a study evaluating the effect of combined salinity with $\mathrm{N}$ doses in spinach, the authors reported a significant decrease in Fe with increased salinity, in agreement with our results but, contrary to our results, they reported small, but significant, increases in $\mathrm{Zn}$ and $\mathrm{Cu}$ as salinity increased [49], which could be a cultivar-specific response. Although other micronutrients were present at similar concentration in roots and shoots, 
$\mathrm{Mn}$ and Fe were found in roots in concentrations 6-fold or higher and 2.5-fold or higher in roots than in shoots, respectively. The data on mineral composition of spinach roots suggest that, instead of being discarded, they should be used as a rich source of Fe, Mn, and of macronutrients for human and animal diets.

\subsection{Effect of Combined Salinity and Potassium Doses on Shoot Mineral Composition}

Our shoot macronutrient data for both 'Raccoon' and Gazelle clearly established that concentrations of N, P, and K were maintained in shoots across salinity levels (Table 3; Figure 6). The increase in shoot $\mathrm{P}$ concentration, mainly observed in 'Gazelle' may have been an attempt for the plant to balance $\mathrm{HPO}_{4}{ }^{2-}$ ions under an increased concentration of $\mathrm{Na}^{+}$, as previously discussed under root mineral composition, and as suggested by others [48]. Similar results on the maintenance of $\mathrm{N}$ concentrations and increased P concentrations in spinach shoots, under similar salinity levels, were reported by others [49]. It has been established earlier that differences in salt tolerance of three brassica species could be related to $\mathrm{K}^{+}$retention in roots [50]. The high salt tolerance of 'Raccoon' and 'Gazelle' may be attributed to their ability to retain $\mathrm{K}^{+}$in both roots and shoots, regardless salinity increase in irrigation waters or the low availability of $\mathrm{K}$ in irrigation waters. This $\mathrm{K}$ homeostasis against its availability in soil or water was discussed at the molecular level elsewhere [8].

Interestingly, shoot micronutrients, in general, showed no significant differences in either cultivar as salinity increased. The concentrations of Fe and Mn were also the highest, as they were in roots, but at much lower magnitudes (Tables S1 and S2).

Homeostasis of N, P, and $\mathrm{K}$ was maintained in both spinach cultivars, regardless of the significant increase in $\mathrm{Na}$ and $\mathrm{Cl}$ and regardless the fact that three of the $\mathrm{K}$ doses were from 10 to 43 times lower than what was considered sufficient for spinach growth in previous works [6,40]. The concentrations of shoot $\mathrm{Ca}, \mathrm{Mg}$, and $\mathrm{S}$, although with significant decreases, were still maintained at levels high enough for plant growth and shoot biomass accumulation, similar to our previous results comparing two doses of $\mathrm{K}\left(0.25\right.$ and $\left.5.0 \mathrm{mmol}_{\mathrm{C}} \mathrm{L}^{-1}\right)$, also under elevated irrigation-water salinity [8].

\subsection{Effect of Combined Salinity and Potassium Doses on Plant Biomass Accumulation}

A similar increase in shoot biomass under low to mild salinity, as the one observed in this study, was reported for 'Raccoon' when irrigation salinity significantly increased total dry matter (roots + shoots) at 30 and $60 \mathrm{mmol}_{\mathrm{C}} \mathrm{L}^{-1}$ [8]. The SDW increase observed with 30 and $60 \mathrm{mmol}_{\mathrm{C}} \mathrm{L}^{-1}$ at the lowest $\mathrm{K}$ dose suggests that plants of both cultivars benefited from $\mathrm{NaCl}$ when $\mathrm{K}$ was deficient (Figure 8). Although salinity increase caused a decrease in RDW at the K doses of 0.15 and $0.30 \mathrm{mmol}_{\mathrm{C}}$ $\mathrm{L}^{-1}$, SDW remained mostly unchanged, regardless of $\mathrm{K}$ dose and salinity levels. However, a small, but significant, decrease in shoot biomass of both cultivars was observed at $0.15 \mathrm{mmol}_{\mathrm{C}} \mathrm{L}^{-1} \mathrm{~K}_{\text {between }}$ control salinity and $160 \mathrm{mmol}_{\mathrm{C}} \mathrm{L}^{-1} \mathrm{NaCl}$. Thus, in general, neither $\mathrm{K}$ nor $\mathrm{NaCl}$ dose had a great impact on SDW of either cultivar.

Previous results with the same cultivars grown in soil under lower $\mathrm{NaCl}$ concentrations (from 5.0 to $120 \mathrm{mmol}_{\mathrm{C}} \mathrm{L}^{-1}$ ) showed a significant decrease in dry shoot biomass for 'Raccoon' after $30 \mathrm{mmol}_{\mathrm{C}} \mathrm{L}^{-1}$ when $\mathrm{K}$ was $5.0 \mathrm{mmol}_{\mathrm{c}} \mathrm{L}^{-1}$, while 'Raccoon' significantly increased SDW with 30-60 mmol $_{\mathrm{C}} \mathrm{L}^{-1} \mathrm{NaCl}$ when $\mathrm{K}$ was $0.25 \mathrm{mmol}_{\mathrm{C}} \mathrm{L}^{-1}$ [8]. This significant increase in shoot biomass with 30-60 $\mathrm{mmol}_{\mathrm{C}} \mathrm{L}^{-1}$ was also observed for both 'Raccoon' and 'Gazelle' when $\mathrm{K}$ dose was $0.07 \mathrm{mmol}_{\mathrm{C}} \mathrm{L}^{-1}$ in this experiment (Figure 8), 3.6-fold less than the deficient dose used by Ferreira and collaborators [8]. Plants in that experiment were cultivated in 1:1 (loamy sandy soil:sand) and submitted to salinity when they had 6-8 true leaves, as in this experiment. Because of the use of loamy sand soil and a leaching fraction of 0.25 (25\% leaching) used by those authors, plants irrigated with 90 and $120 \mathrm{mmol}_{\mathrm{C}}$ $\mathrm{L}^{-1}$ were exposed to soil salinities $\left(E C_{\mathrm{e}}\right)$ of 8.9 to $10.4 \mathrm{dS} \mathrm{m}^{-1}$, respectively, at the end of the experiment. These soil-paste salinities correspond to irrigation-water salinities $\left(\mathrm{EC}_{\mathrm{iw}}\right)$ of 19.6 and $22.9 \mathrm{dS} \mathrm{m}^{-1}$, respectively, thus explaining the significant decrease in shoot biomass at these two salinities. In this study, plants were cultivated in an all-sand medium to reduce $\mathrm{K}$ to deficient levels for seven weeks 
under the salinity treatments, and a leaching fraction of 0.30 was applied. Thus, the low effect of salinity on SDW, even at $160 \mathrm{mmol}_{\mathrm{C}} \mathrm{L}^{-1}\left(\mathrm{EC}_{\mathrm{iw}}=17 \mathrm{dS} \mathrm{m}{ }^{-1}\right)$, can be partly explained by the fact that the sandy medium allowed a more efficient leaching of $\mathrm{NaCl}$, preventing salinity build-up in the pot, and partly because spinach plants may have adapted to $\mathrm{NaCl}$ during the seven weeks (50 days) of cultivation, while in a previous experiment with 'Raccoon', plants were only allowed to grow under salinity for only 28 days [6].

Our results clearly indicate that $\mathrm{K}$ requirements of spinach are much lower relative to the ones previously recommended for the crop (63 to $138 \mathrm{~kg} \mathrm{ha}^{-1}$ or 1.6 to $3.54 \mathrm{mmol}_{\mathrm{c}} \mathrm{L}^{-1}$ ) [41]. Despite the fact that the lowest $\mathrm{K}$ level of $0.07 \mathrm{mmol}_{\mathrm{C}} \mathrm{L}^{-1}$ used (equivalent to $2.73 \mathrm{~kg}$ of K ha ${ }^{-1}$ ) was from 23 to 50 times lower than recommended for spinach fertilization [41], plants maintained $\mathrm{N}, \mathrm{P}$, and $\mathrm{K}$ homeostasis in both roots and shoot, thus sustaining growth. Our results on K requirements confirm previously-reported data with spinach, in which plant biomass was similar under both 0.25 and $5.0 \mathrm{mmol}_{\mathrm{c}} \mathrm{L}^{-1}$ of $\mathrm{K}$ combined to a soil salinity of $\mathrm{EC}_{\mathrm{e}}=6.0 \mathrm{dS} \mathrm{m}^{-1}$ [8], equivalent to the $\mathrm{EC}_{\mathrm{iw}}$ of $13.2 \mathrm{dS} \mathrm{m}^{-1}$ in this study. However, our results disagree with a previous study that reported that spinach plants benefitted from extra $\mathrm{K}$ when salinity increased from 50 to $250 \mathrm{mM} \mathrm{NaCl}$ [51]. In a salinity experiment with 'Raccoon' using sufficient $\mathrm{K}$ doses of 3, 5, and $7 \mathrm{mmol}_{\mathrm{C}} \mathrm{L}^{-1}$, plants grew well up to $80 \mathrm{mmol}_{\mathrm{c}} \mathrm{L}^{-1} \mathrm{NaCl}\left(\mathrm{EC}_{\mathrm{iw}}=9.3-9.8 \mathrm{dS} \mathrm{m}^{-1}\right)$, regardless of the $\mathrm{K}$ doses and had no significant decrease in plant dry weight [6]. A study where spinach was cultivated in a loamy sand soil testing $\mathrm{K}$ doses of $0,63,85,127$, and $148 \mathrm{~kg} \mathrm{ha}^{-1}$, without salinity, reported that spinach shoot dry weight showed no difference among all the $\mathrm{K}$ doses tested [39]. However, those authors did not consider that the loamy soil used could have enough $\mathrm{K}$ for spinach to grow without any additional $\mathrm{K}$ needed in the control dose of $0.0 \mathrm{~kg} \mathrm{ha}^{-1}$. In our experiment, spinach shoot biomass was not generally affected by salinity up to $160 \mathrm{mmol}_{\mathrm{C}} \mathrm{L}^{-1}$, despite significant shoot reductions in $\mathrm{Ca}, \mathrm{Mg}$, and $\mathrm{S}$, and regardless of the very low doses of $\mathrm{K}$ provided. Thus, spinach plants behaved unlike what was expected for glycophytic plants irrigated with water electrical conductivity $\left(\mathrm{EC}_{\mathrm{iw}}\right)$ up to $17 \mathrm{dS} \mathrm{m}^{-1}\left(160 \mathrm{mmol}_{\mathrm{C}} \mathrm{L}^{-1}\right.$ $\mathrm{NaCl}$ ) combined with deficient $\mathrm{K}$ in the growth medium.

Our results show clear differences in shoot biomass between seedlings and older spinach plants in response to the same water-salinity treatments. Plants exposed to salinity at the 6-8 true-leaf stage and allowed to grow for seven weeks into adult plants were more salt-tolerant than seedlings. Eggplant varieties subjected to increasing salinity during germination and seedling stages also responded differently depending on plant growth stage, with salinity tolerance of all cultivars increasing at the later growth stages [36]. Spinach plants, even under very low levels of K maintained optimal plant growth, suggesting that there are genetic mechanisms that are triggered under either low $\mathrm{K}$, or both low $\mathrm{K}$ and high salinity, that are responsible for $\mathrm{K}$ and $\mathrm{N}$, and maybe $\mathrm{P}$, homeostasis in the plant as previously discussed $[8,52,53]$. Our results suggest that spinach plants can tolerate moderate to high salinity in sandy soils, and when applied a leaching fraction of approximately 0.30 , having the ability to adjust to some degree of salinity as plants grow older. Thus, saline waters would be better suited for the production of "freezer spinach" (older plants) than of "baby spinach" as the former is harvested at a later developmental stage with mineral nutrient concentrations that can be twice that of baby spinach [41]. However, these results obtained in sand culture must be interpreted carefully and cannot be directly extrapolated to field cultivation under different leaching regimes before experimenting with the target soil to be used for spinach cultivation. Results clearly suggest that the salinity threshold of spinach, even under deficient levels of $K$ in the soil solution, is higher than the previously reported $\mathrm{EC}_{\mathrm{e}}$ of $2.0 \mathrm{dS} \mathrm{m}^{-1}$ (estimated $\mathrm{EC}_{\mathrm{iw}}=4.4 \mathrm{dS} \mathrm{m}^{-1}$ ) [54-56]. Based on the $\mathrm{EC}_{\mathrm{iw}}$ of $17 \mathrm{dS} \mathrm{m}^{-1}$ tested here, we can estimate an $\mathrm{EC}_{\mathrm{e}}=7.7 \mathrm{dS} \mathrm{m}^{-1}$ for 'Raccoon' and Gazelle, or 3.85-fold higher than the $\mathrm{EC}_{\mathrm{e}}$ provided for spinach (no cultivar mentioned) by the previous authors.

\section{Concluding Remarks}

In general, spinach did not respond to $K$ doses either during germination or vegetative growth and there was no interaction between salinity and K. However, salinity decreased germination parameters 
of Gazelle at the highest $\mathrm{NaCl}$ dose, and drastically reduced seedling biomass at every increase in $\mathrm{NaCl}$ for 'Raccoon' but only at 120 and $160 \mathrm{mmol}_{\mathrm{c}} \mathrm{L}^{-1}$ for Gazelle, indicating that Gazelle was more tolerant to salinity than 'Raccoon' during germination and seedling establishment, the most salt-susceptible stage. Interestingly, germination \% of 'Raccoon' improved significantly at $60 \mathrm{mmol}_{\mathrm{C}}$ $\mathrm{L}^{-1} \mathrm{NaCl}$, suggesting that moderate salinity can improve the germination of this cultivar. Our results also indicate that the responses of spinach to salinity depends on the plant growth stage and on the cultivar. At the later growth stage, 'Raccoon' and Gazelle were both tolerant to irrigation waters of moderate to high salinity.

Mature plants of both cultivars accumulated large concentrations of $\mathrm{Na}$ and $\mathrm{Cl}$ in both roots and shoots, and these ions could have contributed to osmotic balance to maintain cell turgor without causing symptoms of ion toxicity. Both cultivars maintained their macro and micronutrient at adequate, or close to adequate, tissue levels for growth. Even under severe $\mathrm{K}$ deficiency $\left(0.07 \mathrm{mmol}_{\mathrm{c}} \mathrm{L}^{-1}\right.$, equivalent to a range of 23- to 50 -fold less $\mathrm{K}$ than recommended for the crop), adult plants maintained $\mathrm{K}$ concentrations over the minimum required $\left(20 \mathrm{~g} \mathrm{~kg}^{-1} \mathrm{SDW}\right)$ for plant growth. Therefore, mature plants are more salt tolerant than young plants and saline waters would be better adapted to the production of "freezer spinach" (vegetatively mature plants) instead of "baby spinach" (young plants).

The increase in $\mathrm{K}$ from deficient to sufficient reduced the Na:K ratio in the shoots, regardless of the level of salinity but the beneficial effects of K on RDW and SDW were observed only at lowest level of salinity $\left(5 \mathrm{mmol}_{\mathrm{C}} \mathrm{L}^{-1} \mathrm{NaCl}\right)$. This demonstrates that the improvement in the nutritional status of the plant does not overcome the osmotic effects associated with the increase in the total concentration of salts in the root zone.

Plants from both cultivars seemed to benefit from salinity at the lowest $\mathrm{K}$ dose of $0.07 \mathrm{mmol}_{\mathrm{C}} \mathrm{L}^{-1}$ with shoot biomass increasing significantly at $60 \mathrm{mmol}_{\mathrm{C}} \mathrm{L}^{-1}$ of NaCl . Although not significant, a similar trend for increased root biomass was also observed for both cultivars. Although we assume that this salinity benefit was only caused by $\mathrm{Na}^{+}$(ions), as an osmoticum to maintain cell turgor but not as a substitute of $\mathrm{K}^{+}$in its physiological function, salinity treatments above control levels had similar concentrations of $\mathrm{Cl}^{-}$. Regarding mineral tissue accumulation, $\mathrm{Cl}$ tissue accumulation was as substantial as that of $\mathrm{Na}$. Interestingly, $\mathrm{Cl}$ is recognized to be essential to plant growth only at micronutrient levels $\left(\mathrm{mg} \mathrm{kg}^{-1}\right)$, while $\mathrm{Na}$ is a needed nutrient for the growth of halophytes, but not of glycophytes, such as spinach. The spinach cultivars studied here have demonstrated to be salt tolerant and our results for Na:K ratio confirmed the results of a previous study with the same cultivars that reported that sufficient $\mathrm{K}$ decreases $\mathrm{Na}$ tissue accumulation.

Of course, these results cannot be directly extrapolated to field cultivation of spinach in general because salinity tolerance depends on the cultivar, type of soil, season, and irrigation frequency applied. What is clear is that $\mathrm{K}$ fertilization can be significantly decreased to increase farmer profits. These results also raise the question: Is $\mathrm{K}$ the only mineral that can be drastically reduced in spinach cultivation or would similar shoot biomass be achieved with $\mathrm{N}$ reduction? At a time that more food is needed to feed a growing world population and freshwater becomes scarcer and more expensive, or is unavailable, for irrigation in arid and semiarid areas of the planet, we must revisit mineral needs for crops cultivated under saline irrigation as a way to maintain food production, increase farmer's profits, while decreasing agriculture footprint and slowing down the salinization of our soils and water resources.

Spinach seems to be a salt-tolerant glycophyte in a family (Amaranthaceae) that has halophytes such as Salicornia spp., Sarcocornia spp., Suaeda spp., Chenopodium spp., and Atriplex spp., which have all adapted to saline and arid environments. The fact that germination percent improved with time and that plants showed no significant decrease in biomass at the adult stage, regardless of $\mathrm{K}$ dose and after 50 days of irrigation with moderate to high-salinity waters lead us to conclude that spinach can be successfully cultivated with saline recycled waters in arid and semiarid regions and requires much less $\mathrm{K}$ fertilization than previously recommended. 
Supplementary Materials: The following are available online at http://www.mdpi.com/2223-7747/9/12/1739/s1, Table S1: Concentrations of micronutrients in roots and shoots of 'Raccoon' for the respective combinations of $\mathrm{NaCl}$ (5.0 to $160.0 \mathrm{mmol}_{\mathrm{C}} \mathrm{L}^{-1}$ ) and $\mathrm{K}$ doses $\left(0.07\right.$ to $3.0 \mathrm{mmol}_{\mathrm{C}} \mathrm{L}^{-1}$ ), Table S2: Concentrations of micronutrients in roots and shoots of 'Gazelle' for the respective combinations of $\mathrm{NaCl}\left(5.0\right.$ to $\left.160.0 \mathrm{mmol}_{\mathrm{C}} \mathrm{L}^{-1}\right)$ and $\mathrm{K}$ doses $(0.07$ to $3.0 \mathrm{mmol}_{\mathrm{C}} \mathrm{L}^{-1}$ ).

Author Contributions: Conceptualization, J.F.S.F.; data curation, X.L. and J.B.d.S.F.; formal analysis, K.U. and J.B.d.S.F.; investigation, J.F.S.F., D.S., D.L.S., and X.L.; methodology, J.F.S.F. and X.L.; project administration, J.F.S.F. and X.L.; visualization, J.F.S.F., K.U., J.B.d.S.F., and D.S.; writing, initial drafts, K.U. and J.F.S.F.; writing, review and editing, J.F.S.F., K.U., C.F.d.L., D.S., D.L.S., and X.L. All authors have read and agreed to the published version of the manuscript.

Funding: This research was funded by the United States Department of Agriculture (USDA-ARS) as part of the internal project: CRIS 2036-13210-006-00D; Enhancing Special Crop Tolerance to Saline Irrigation Waters.

Acknowledgments: We acknowledge the financial support of a grant provided by TUBITAK (2219 International Postdoctoral Research Scholarship Program) for Kadir Uçgun's work on this project at the US Salinity Laboratory (USDA-ARS), Riverside, USA. We also acknowledge the help of Alysia Soria, Kimberly Wilkerson, and Noah Gangoso for their assistance with harvest, saline solutions and sample preparation and Pangki Xiong for the analyses of macro/micronutrients and of $\mathrm{Na}$ and $\mathrm{Cl}$ in tissues of spinach. We also acknowledge the help of Ray Anderson and Dennise Jenkins for the confirmation of greenhouse light intensity.

Conflicts of Interest: The authors declare no conflict of interest. The U.S. Department of Agriculture (USDA) prohibits discrimination in all programs and activities on the basis of race, color, national origin, age, disability and, where applicable, sex, marital status, familial status, parental status, religion, sexual orientation, genetic information, political beliefs, reprisal, or because all or part of an individual's income is derived from any public assistance program (not all prohibited basis apply to all programs). USDA is an equal opportunity provider and employer. Mention of commercial products and organizations in this manuscript is solely to the benefit of the reader and it does not constitute endorsement by the USDA-ARS over other products and organizations not mentioned.

\section{References}

1. Ashraf, M. Breeding for salinity tolerance in plants. Crit. Rev. Plant Sci. 1994, 13, 17-42. [CrossRef]

2. Levitt, J. Responses of Plants to Environmental Stresses, Water, Radiation, Salt and Other Stresses; Academic Press: New York, NY, USA, 1980.

3. Munns, R. Comparative physiology of salt and water stress. Plant Cell Environ. 2002, 25, 239-250. [CrossRef] [PubMed]

4. Hu, Y.; Schmidhalter, U. Drought and salinity: A comparison of their effects on mineral nutrition of plants. J. Plant Nutr. Soil Sci. 2005, 168, 541-549. [CrossRef]

5. Dias, N.S.; Ferreira, J.F.S.; Liu, X.; Suarez, D.L. Jerusalem artichoke (Helianthus tuberosus L.) maintains high inulin, tuber yield, and antioxidant capacity under moderately-saline irrigation waters. Ind. Crops Prod. 2016, 94, 1009-1024. [CrossRef]

6. Ferreira, J.F.S.; Sandhu, D.; Liu, X.; Halvorson, J.J. Spinach (Spinacea oleracea L.) response to salinity: Nutritional value, physiological parameters, antioxidant capacity, and gene expression. Agriculture 2018, 8, 163. [CrossRef]

7. Ferreira, J.F.S.; Cornacchione, M.; Liu, X.; Suarez, D. Nutrient Composition, Forage Parameters, and Antioxidant Capacity of Alfalfa (Medicago sativa, L.) in Response to Saline Irrigation Water. Agriculture 2015, 5, 577-597. [CrossRef]

8. Ferreira, J.F.S.; da Silva, J.B.; Liu, X.; Sandhu, D. Spinach plants favor the absorption of $\mathrm{K}^{+}$over $\mathrm{Na}^{+}$regardless of salinity, and may benefit from $\mathrm{Na}^{+}$when $\mathrm{K}^{+}$is deficient in the soil. Plants 2020, 9, 507. [CrossRef]

9. Ferreira, J.F.S.; Liu, X.; Suarez, D.L. Fruit yield and survival of five commercial strawberry cultivars under field cultivation and salinity stress. Sci. Hortic. 2019, 243, 401-410. [CrossRef]

10. Suarez, D.L.; Grieve, C.M. Growth, Yield, and Ion Relations of Strawberry in Response To Irrigation With Chloride-Dominated Waters. J. Plant Nutr. 2013, 36, 1963-1981. [CrossRef]

11. Chinnusamy, V.; Jagendorf, A.; Zhu, J.K. Understanding and improving salt tolerance in plants. Crop Sci. 2005, 45, 437-448. [CrossRef]

12. Song, J.; Fan, H.; Zhao, Y.; Jia, Y.; Du, X.; Wang, B. Effect of salinity on germination, seedling emergence, seedling growth and ion accumulation of a euhalophyte Suaeda salsa in an intertidal zone and on saline inland. Aquat. Bot. 2008, 88, 331-337. [CrossRef] 
13. Zhou, D.; Xiao, M. Specific ion effects on the seed germination of sunflower. J. Plant Nutr. 2010, 33, 255-266. [CrossRef]

14. Gomes-Filho, E.; Lima, C.R.F.M.; Costa, J.H.; Da Silva, A.C.M.; Da Guia Silva Lima, M.; De Lacerda, C.F.; Prisco, J.T. Cowpea ribonuclease: Properties and effect of $\mathrm{NaCl}$-salinity on its activation during seed germination and seedling establishment. Plant Cell Rep. 2008, 27, 147-157. [CrossRef] [PubMed]

15. Yupsanis, T.; Moustakas, M.; Eleftheriou, P.; Damianidou, K. Protein phosphorylation-dephosphorylation in alfalfa seeds germinating under salt stress. J. Plant Physiol. 1994, 143, 234-240. [CrossRef]

16. Dantas, B.F.; De Sá Ribeiro, L.; Aragão, C.A. Germination, initial growth and cotyledon protein content of bean cultivars under salinity stress. Rev. Bras. Sementes 2007, 29, 106-110. [CrossRef]

17. Khan, M.A.; Rizvi, Y. Effect of salinity, temperature, and growth regulators on the germination and early seedling growth of Atriplex griffithii var. stocksii. Can. J. Bot. 1994, 72, 475-479. [CrossRef]

18. Promila, K.; Kumar, S. Vigna radiata seed germination under salinity. Biol. Plant. 2000, 43, $423-426$. [CrossRef]

19. Tawaha, A.M.; Othman, Y.; Al-Karaki, G.; Al-Tawaha, A.R.; Al-Horani, A. Variation in germination and ion uptake in barley genotypes under salinity conditions. World J. Agric. Sci. 2006, 2, 11-15.

20. Turhan, A.; Kuşcu, H.; Şeniz, V. Effects of different salt concentrations ( $\mathrm{NaCl})$ on germination of some spinach cultivars. Uludağ Üniv. Ziraat Fak. Derg. 2011, 25, 65-77. [CrossRef]

21. Borsai, O.; Al-Hassan, M.; Boscaiu, M.; Sestras, R.E.; Vicente, O. Effects of salt and drought stress on seed germination and seedling growth in Portulaca. Rom. Biotechnol. Lett. 2018, 23, 13340-13349.

22. Sandhu, D.; Cornacchione, M.V.; Ferreira, J.F.S.; Suarez, D.L. Variable salinity responses of 12 alfalfa genotypes and comparative expression analyses of salt-response genes. Sci. Rep. 2017, 7. [CrossRef] [PubMed]

23. Sandhu, D.; Pudussery, M.V.; Ferreira, J.F.S.; Liu, X.; Pallete, A.; Grover, K.K.; Hummer, K. Variable salinity responses and comparative gene expression in woodland strawberry genotypes. Sci. Hortic. 2019, 254, 61-69. [CrossRef]

24. Zrig, A.; Ferreira, J.F.S.; Serrano, M.; Valero, D.; Tounekti, T.; Khemira, H. Polyamines and other secondary metabolites of green-leaf and red-leaf almond rootstocks trigger in response to salinity. Pak. J. Bot. 2018, $50,1273-1279$.

25. Abdul Jaleel, C.; Gopi, R.; Sankar, B.; Manivannan, P.; Kishorekumar, A.; Sridharan, R.; Panneerselvam, R. Studies on germination, seedling vigour, lipid peroxidation and proline metabolism in Catharanthus roseus seedlings under salt stress. S. Afr. J. Bot. 2007, 73, 190-195. [CrossRef]

26. Kaymakanova, M. Effect of salinity on germination and seed physiology in bean (Phaseolus vulgaris L.). Biotechnol. Biotechnol. Equip. 2009, 23, 326-329. [CrossRef]

27. Prado, F.E.; Boero, C.; Gallardo, M.; González, J.A. Effect of $\mathrm{NaCl}$ on germination, growth, and soluble sugar content in Chenopodium quinoa Willd. seeds. Bot. Bull. Acad. Sin. 2000, 41, 27-34. [CrossRef]

28. Brakez, M.; Harrouni, M.C.; Tachbibi, N.; Daoud, S. Comparative effect of $\mathrm{NaCl}$ and seawater on germination of quinoa seed (Chenopodium quinoa willd). Emir. J. Food Agric. 2014, 26, 1091-1096. [CrossRef]

29. Al-Harbi, A.R.; Wahb-Allah, M.A.; Abu-Muriefah, S.S. Salinity and nitrogen level affects germination, emergence, and seedling growth of tomato. Int. J. Veg. Sci. 2008, 14, 380-392. [CrossRef]

30. Jamil, M.; Lee, D.B.A.E.; Jung, K.Y.; Ashraf, M.; Chun, S.; Rha, E.U.I.S. Effect of salt (Nacl) stress on germination and early seedling growth of four vegetables species. J. Cent. Eur. Agric. 2006, 7, 273-282. [CrossRef]

31. Janagard, M.S.; Tobeh, A.; Esmailpour, B. Evaluation of salinity tolerance of three canola cultivars at germination and early seedling growth stage. J. Food Agric. Environ. 2008, 6, 272-275.

32. Abdel-Haleem, A.; El-Shaieny, H. Seed germination percentage and early seedling establishment of five (Vigna unguiculata L. (Walp) genotypes under salt stress. Eur. J. Exp. Biol. 2015, 5, 22-32.

33. Alemzadeh, N.; Khaleghi, A.S. Germination and emergence response of some onion cultivars of Southern Iran to salinity stress. Seed Sci. Biotechnol. 2009, 3, 21-23.

34. Kaya, M.D.; Ipek, A.; Öztürk, A. Effects of different soil salinity levels on germination and seedling growth of safflower (Carthamus tinctorius L.). Turk. J. Agric. For. 2003, 27, 221-227. [CrossRef]

35. Wu, G.Q.; Jiao, Q.; Shui, Q.Z. Effect of salinity on seed germination, seedling growth, and inorganic and organic solutes accumulation in sunflower (Helianthus annuus L.). Plant Soil Environ. 2015, 61, 220-226. [CrossRef] 
36. Akinci, I.E.; Akinci, S.; Yilmaz, K.; Dikici, H. Response of eggplant varieties (Solanum melongena) to salinity in germination and seedling stages. N. Z. J. Crop Hortic. Sci. 2004, 32, 193-200. [CrossRef]

37. Kahouli, B.; Borgi, Z.; Hannachi, C. Effect of sodium chloride on the germination of the seeds of a collection of carrot accessions (Daucus carota L.) cultivated in the region of Sidi Bouzid. J. Stress Physiol. Biochem. 2014, 10, 28-36.

38. Subbarao, G.V.; Wheeler, R.M.; Stutte, G.W.; Levine, L.H. How-far can sodium substitute for potassium in red beet? J. Plant Nutr. 1999, 22, 1745-1761. [CrossRef]

39. Nemadodzi, L.E.; Araya, H.; Nkomo, M.; Ngezimana, W.; Mudau, N.F. Nitrogen, phosphorus, and potassium effects on the physiology and biomass yield of baby spinach (Spinacia oleracea L.). J. Plant Nutr. 2017, 40, 2033-2044. [CrossRef]

40. Ors, S.; Suarez, D.L. Salt tolerance of spinach as related to seasonal climate. Hortic. Sci. 2016, 43, 33-41. [CrossRef]

41. Koike, S.T.; Cahn, M.; Fennimore, S.; Lestrange, M.; Natwick, E.; Smith, R.F.; Takele, E. Vegetable Production Series in Spinach Production in California; Publication 7212; University of California Agricultural and Natural Resources: Davis, CA, USA, 2011; 6p.

42. Karege, F.; Penel, C.; Greppin, H. Floral induction in spinach leaves by light, temperature and gibberellic acid: Use of the photocontrol of basic peroxidase activity as biochemical marker. Z. Pflanzenphysiol. 1982, 107, 357-365. [CrossRef]

43. Kader, M.A. A Comparison of seed germination calculation formulae and the associated interpretation of resulting data. J. Proc. R. Soc. N. S. W. 2005, 138, 65-75.

44. Hoagland, D.R.; Arnon, D.I. The Water-Culture Method for Growing Plants without Soil; California Agricultural Experiment Station: Berkeley, CA, USA, 1950; Volume Circular 347, 32p.

45. Ribeiro Junior, J.I.; Melo, A.L.P. Guia Prático Para Utilização do Saeg; Folha Artes Graficas Ltd.: Viçosa, Brazil, 2008.

46. Lacerda, C.F.; Ferreira, J.F.S.; Liu, X.; Suarez, D.L. Evapotranspiration as a criterion to estimate nitrogen requirement of maize under salt stress. J. Agron. Crop Sci. 2016, 202, 192-202. [CrossRef]

47. Morgan, K.T. (Ed.) Nutrient Management of Vegetable and Row Crops Handbook (SP500); University of Florida: Gainesville, FL, USA, 2015.

48. Schröppel-Meier, G.; Kaiser, W.M. Ion homeostasis in chloroplasts under salinity and mineral deficiency. Plant Physiol. 1988, 87, 828-832. [CrossRef] [PubMed]

49. Sheikhi, J.; Ronaghi, A. Growth and macro and micronutrients concentration in spinach (Spinacia oleracea L.) as influenced by salinity and nitrogen rates. Int. Res. J. Appl. Basic Sci. 2012, 3, 770-777.

50. Chakraborty, K.; Bose, J.; Shabala, L.; Shabala, S. Difference in root $\mathrm{K}^{+}$retention ability and reduced sensitivity of $\mathrm{K}^{+}$-permeable channels to reactive oxygen species confer differential salt tolerance in three Brassica species. J. Exp. Bot. 2016, 67, 4611-4625. [CrossRef] [PubMed]

51. Chow, W.; Ball, M.; Anderson, J. Growth and photosynthetic responses of spinach to salinity: Implications of $\mathrm{K}+$ nutrition for salt tolerance. Funct. Plant Biol. 1990, 17, 563. [CrossRef]

52. Raddatz, N.; Morales de los Ríos, L.; Lindahl, M.; Quintero, F.J.; Pardo, J.M. Coordinated transport of nitrate, potassium, and sodium. Front. Plant Sci. 2020, 11, 247. [CrossRef]

53. Ragel, P.; Raddatz, N.; Leidi, E.O.; Quintero, F.J.; Pardo, J.M. Regulation of $\mathrm{K}^{+}$nutrition in plants. Front. Plant Sci. 2019, 10. [CrossRef]

54. Grieve, C.; Grattan, S.; Maas, E. Plant salt tolerance. In Agricultural Salinity Assessment and Management; Wallender, W.W., Tanji, K.K., Eds.; ASCE Press: Reston, VA, USA, 2012; pp. 405-459.

55. Maas, E.V.; Grattan, S.R. Crop Yields as Affected by Salinity. In Agricultural Drainage; Skaggs, R.W., Schilfgaarde, J.V., Eds.; ASA/CSSA/SSSA: Madison, WI, USA, 1999; pp. 55-108.

56. Maas, E.V.; Hoffman, G.J. Crop salt tolerance-current assessment. J. Irrig. Drain. Div. 1977, 103, $115-134$.

Publisher's Note: MDPI stays neutral with regard to jurisdictional claims in published maps and institutional affiliations. 